OAK RIDGE NATIONAL LABORATORY

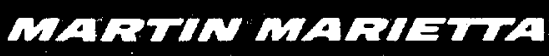

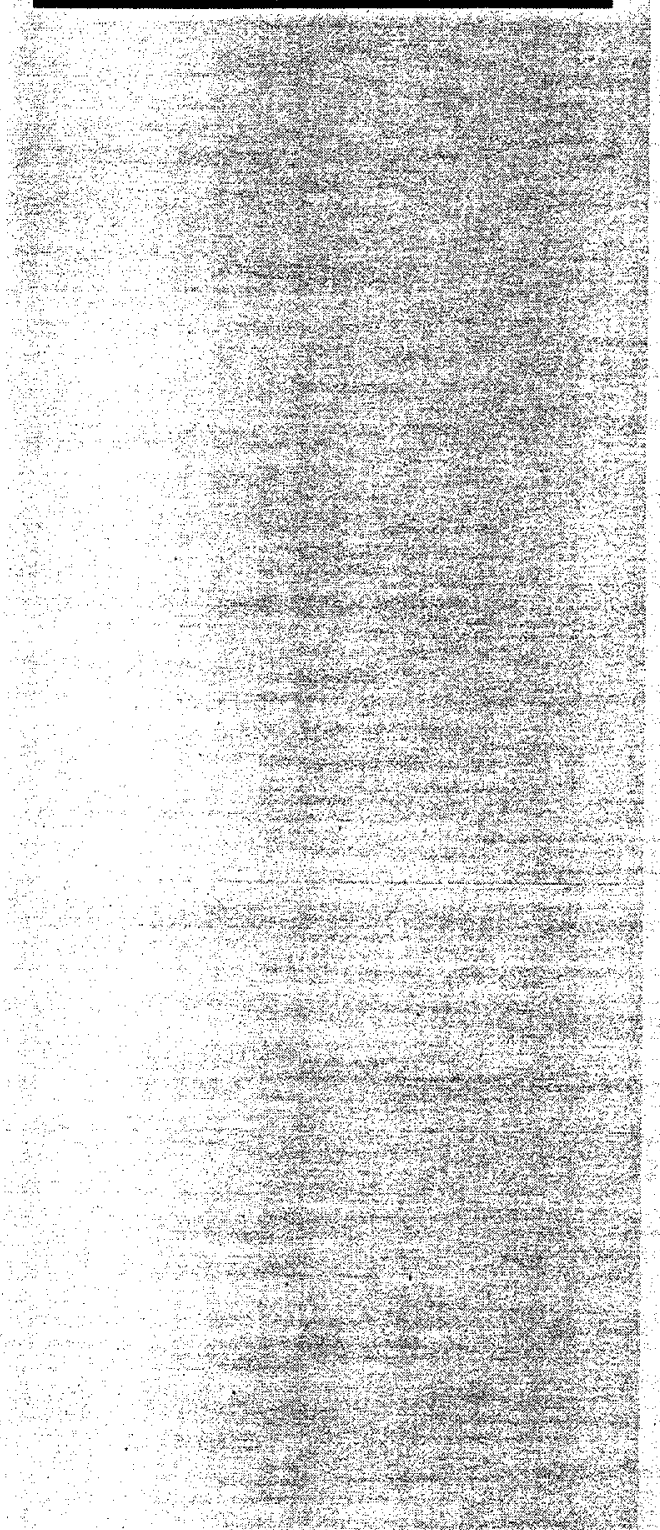

MARTIN MARIETTA ENERGY SYSTEMS, INC.

FOR THE UNITED STATES

DEPARTMENT OF ENERGY

\section{Estimating Potential Stranded
mmitments for U.S. Investor-Owned \\ Estimating Potential Stranded
Commitments for U.S. Investor-Owned Electric Utilities}

Lester Baxter

Eric Hirst 
This report has been reproduced directly from the best available copy.

Available to DOE and DOE contractors from the Office of Scientific and Technical Information, P.O. Box 62, Oak Ridge, TN 37831; prices available from (615) 576-8401, FTS 626-8401.

Available to the public from the National Technical Information Service, U.S. Department of Commerce, 5285 Port Royal Rd., Springfield, VA 22161.

This report was prepared as an account of work sponsored by an agency of the United States Government. Neither the United States Government nor any agency thereof, nor any of their employees, makes any warranty, express or implied, or assumes any legal liability or responsibility for the accuracy, completeness, or usefulness of any information, apparatus, product, or process disclosed, or represents that its use would not infringe privately owned rights. Reference herein to any specific commercial product, process, or service by trade name, trademark, manufacturer, or otherwise, does not necessarily constitute or imply its endorsement, recommendation, or favoring by the United States Government or any agency thereof. The views and opinions of authors expressed herein do not necessarily state or reflect those of the United States Government or any agency thereof. 


\section{ENERGY DIVISION}

\section{ESTIMATING POTENTIAL STRANDED COMMITMENTS FOR U.S. INVESTOR-OWNED ELECTRIC UTILITIES}

LESTER BAXTER and ERIC HIRST

January 1995

Sponsored by Office of Energy Efficiency and Renewable Energy U.S. Department of Energy

OAK RIDGE NATIONAL LABORATORY

Oak Ridge, Tennessee 37831 managed by

MARTIN MARIETTA ENERGY SYSTEMS, INC.

for the

U.S. DEPARTMENT OF ENERGY

under contract No. DE-AC05-84OR21400 


\section{CONTENTS}

Page

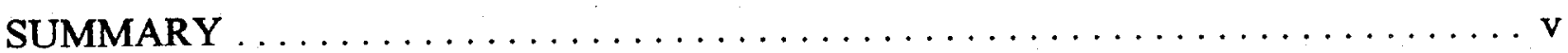

LIST OF ACRONYMS $\ldots \ldots \ldots \ldots \ldots \ldots \ldots \ldots \ldots \ldots \ldots \ldots \ldots \ldots \ldots \ldots \ldots \ldots$ vii

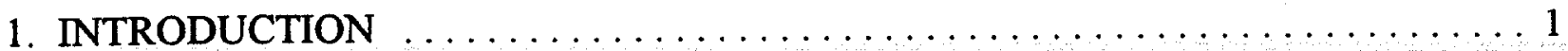

2. PRIOR ESTIMATES OF STRANDED COMMITMENTS $\ldots \ldots \ldots \ldots \ldots \ldots \ldots 3$

3. ALTERNATIVE WAYS TO COMPUTE STRANDED COMMITMENTS $\ldots \ldots \ldots 7$

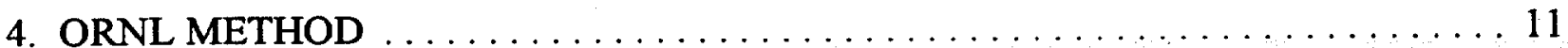

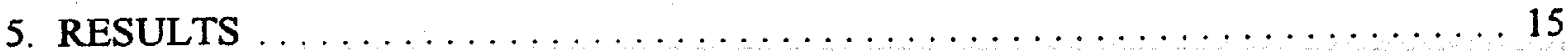

6. OUR ASSUMPTIONS AND THEIR VALIDITY $\ldots \ldots \ldots \ldots \ldots \ldots \ldots \ldots \ldots$

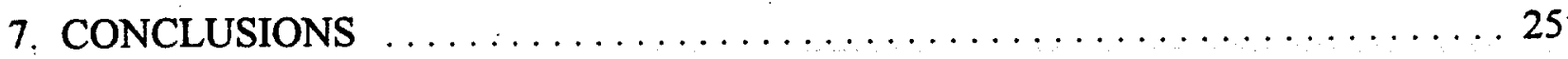

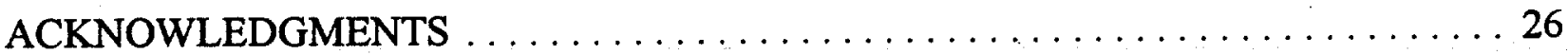

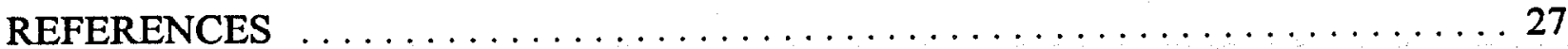

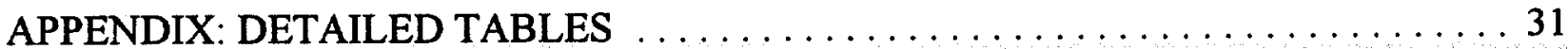




\section{SUMMARY}

New technologies, low natural gas prices, and federal and state utility regulations are restructuring the electricity industry. Yesterday's vertically integrated utility with a retail monopoly franchise may be a very different organization in a few years. Conferences, regulatorycommission hearings, and other industry fora are dominated by debates over the extent and form of utility deintegration, wholesale competition, and retail wheeling.

A key obstacle to restructuring the electricity industry is stranded commitments. Past investments, power-purchase contracts, and public-policy-driven programs that made sense in an era of cost-of-service regulation may not be cost-effective in a competitive power market. Regulators, utilities, and other parties face tough decisions concerning the mitigation and allocation of these stranded commitments.

We developed and applied a simple method to calculate the amount of stranded commitments facing U.S. investor-owned electric utilities. The results obtained with this method depend strongly on a few key assumptions: (1) the fraction of utility sales that is at risk with respect to competition, (2) the market price of electric generation, and (3) the number of years during which the utility would lose money because of differences between its embedded cost of production and the market price.

We calculated stranded commitments assuming that only industrial customers could "leave" the local utility's system or that all retail customers would have such options. We assumed that the appropriate market price was the capital crsts plus operating costs of a combined-cycle combustion turbine or a price between that of the combined-cycle unit and shortrun operating cost based on the region's capacity margin. We tested the sensitivity of results to two other assumed prices: the regional average industrial price or the short-run operating cost of existing generation. We assumed that these losses would occur for five, ten, or fifteen years. We used the nine North American Electric Reliability Council regions to define the boundaries for the regional power markets.

Estimates of stranded commitment can vary widely depending on the assumptions used. We believe that such losses could range from less than $40 \%$ to more than $50 \%$ of utility equity (Table S-1). The lower number might obtain if only industrial customers can leave the system and if the market price of electricity is a function of capacity margins in the region and ranges between the combined-cycle cost and the short-term operating cost. The higher value might occur if all retail customers have choices and the market price is that of a combined-cycle unit. In both 
cases, losses are concentrated in a few states, including California, New York, Ohio, and Pennsylvania Utilities in Kentucky, Missouri, Montana, Virginia, and Washington, on the other hand, face little threat of stranded commitments.

Table S-1. Potential stranded commitment in billions of 1992 dollars (and as percent of equity) as a function of portion of load at risk and market price of generation

\begin{tabular}{lcccc}
\hline & \multicolumn{4}{c}{ Market price $^{\mathrm{a}}$} \\
\cline { 2 - 5 } $\begin{array}{l}\text { Portion of } \\
\text { load at risk }\end{array}$ & $\begin{array}{c}\text { Industrial } \\
\text { average }\end{array}$ & $\begin{array}{c}\text { Combined-cycle } \\
\text { turbine }\end{array}$ & $\begin{array}{c}\text { Capacity } \\
\text { adjusted }\end{array}$ & $\begin{array}{c}\text { Short-run } \\
\text { marginal cost }\end{array}$ \\
\hline $\begin{array}{l}\text { Industrial only } \\
\text { All retail }\end{array}$ & $15(8 \%)$ & $34(19 \%)$ & $69(38 \%)$ & $83(45 \%)$ \\
\hline
\end{tabular}

${ }^{a}$ The assumed market prices decline from left to right.

At any market price, the loss to utility shareholders is 2.5 to 3 times as great when all retail loads are at risk than when only industrial loads are at risk. Raising the assumed market price of electricity by $1 \propto / \mathrm{kWh}$ decreases the equity loss by 25 percentage points for all retail customers and by 10 percentage points for the industrial class only. Lowering the market price by $1 \notin / \mathrm{kWh}$ increases the equity loss by 33 and 14 percentage points, respectively. For the all-retail case, the change in stranded commitments is about $\$ 60$ billion for every $1.0 \% / \mathrm{kWh}$ change in the market price of electricity.

If these earnings losses occur unchanged for only five years (rather than the ten years assumed above), the equity loss would be cut by $40 \%$. On the other hand, if the revenue losses were to occur for 15 years, then the equity loss would increase by almost $30 \%$.

The range of results presented here illustrates the importance of the assumptions used to estimate the amounts of stranded commitments that individual utilities might face. Regulatory commissions need to examine closely the underlying assumptions, as well as the data and analytical tools, used to develop these estimates in deciding how to mitigate and allocate these costs. 


\section{LIST OF ACRONYMS}

CCCT Combined-cycle combustion turbine

ECAR East Central Area Reliability Coordination Agreement

EIA Energy Information Administration

ERCOT Electric Reliability Council of Texas

FERC Federal Energy Regulatory Commission

IOU Investor-owned utility

MAIN Mid-American Interpool Network

MAAC Mid-Atlantic Area Council

MAPP Mid-Continent Area Power Pool

NERC North American Electric Reliability Council

NPCC Northeast Power Coordinating Council

NPV Net present value

SC Stranded commitments

SERC Southeastern Electric Reliability Council

SPP Southwest Power Pool

WSCC Western Systems Coordinating Council 


\section{INTRODUCTION}

Technology advances, low natural gas prices, and legislative initiatives are changing the electricity industry. Because of the 1978 Public Utility Regulatory Policies Act, electric utilities are no longer the sole providers of generation capacity in the United States. The Energy Policy Act of 1992 mandates open and nondiscriminatory access to the transmission system for all suppliers. Many customers (especially the large industrials) want the freedom to choose their electricity provider over this open transmission system. As a result, future industry restructuring could lead to widespread competition among suppliers to meet customer demands.

With widespread competition, a utility will use its own generation mix to compete for market share with other suppliers. If the utility's rates exceed market-clearing prices for electricity, then the utility has a strong incentive to reduce its rates to maintain market share. These price reductions, however, will reduce the utility's revenues and earnings. If the revenue from the sale of its output is now less than its total (capital and operating) cost of production, then some commitments the utility made in the past are now uneconomical.

These two forces, the loss of revenues needed to cover costs and the existence of uneconomical commitments, explain why utilities are concerned that their existing commitments may become "stranded," that is, commitments that no one explicitly pays for.

The policy relevance of these uneconomical commitments is that utilities made them during an era of prudence review and public regulation. Regulators considering industry restructuring must squarely address how to deal with commitments that now appear to be uneconomical but that the industry made with the regulators' approval and with the expectation that the long-standing regulatory compact (which includes the utility's obligation to serve all customers in return for a retail monopoly franchise) would continue. By proposing to alter the regulatory compact by changing the industry structure, regulators raise serious policy questions about uneconomical utility commitments. If the commitments were deemed prudent under the traditional regulatory compact, who bears the burden of paying for the undepreciated balance of these commitments in the restructured industry? How large is this stranded-commitment burden? How should this amount be determined? To what extent can it be reduced?

Stranded commitments (SC) can include four classes of costs (Niagara Mohawk Power Corp. 1994):

Stranded assets, primarily in expensive power plants and excess capacity 
- Stranded liabilities, primarily in power-purchase contracts (including those with qualifying facilities) and deferred income taxes

- Regulatory assets (whose value is based on regulatory decisions rather than on market forces), including deferred expenses and costs for demand-side management programs that regulators allow utilities to place on their balance sheets

- Stranded public-policy programs, including tax collection, environmental compliance beyond that required by law, demand-side management programs paid for by all customers, special programs for low-income customers, and support for energy research and development.

A full treatment of SC would consider (1) alternative ways to calculate SC; (2) estimates of the amount of SC for each utility; (3) methods to mitigate (reduce) these amounts; and (4) allocation of the remaining SC among utility shareholders, different classes of customers, and governments (i.e., taxpayers in general). This report, the first output from a larger Oak Ridge National Laboratory project on stranded commitments, deals only with the first two issues. See Hogan (1994) and Steinmeier and Stuntz (1994) for initial discussions of the latter two issues.

Chapter 2 illustrates the wide range in estimates of SC that exist today and explains the various factors that account for this large range. Chapter 3 discusses alternative ways to calculate SC, and Chapter 4 presents our approach to these computations. Chapter 5 presents our results, and Chapter 6 identifies the key assumptions that underlie our analysis. Chapter 7 offers initial conclusions concerning methods to calculate SC and the resultant amounts. The Appendix contains several tables that provide additional details on the assumptions and results presented here. 


\section{PRIOR ESTIMATES OF STRANDED COMMITMENTS}

Estimates of SC vary widely. Niagara Mohawk (1994) estimates these costs "as high as 150 to 200 billion dollars, compared to a total shareholder equity of 180 billion dollars." Perl (1994) states that "if rates charged for generation were to fall to marginal cost (with no change in transmission or distribution charges) the market value of utility capital would fall by more than $\$ 500$ billion. Since the market value of utility stock is about $\$ 250$ billion, this provides a pretty good picture of disaster. Even if only industrial rates were driven to marginal cost, the value of utility capital would fall by $\$ 160$ billion ... ." At the other end of the spectrum, Hobart (1994) estimates these potential losses at $\$ 10$ to $\$ 20$ billion. Unfortunately, some of these estimates were not supported by data and analysis in the publication cited, which makes it difficult to examine and assess the assumptions used to develop these numbers.

The high estimates cited above may be based on notions of gross SC, which would include only the noneconomical assets, contracts, and so on. Estimates of net SC would reflect the difference between uneconomical and economical assets, where economical assets are those whose market value is higher than book value.

To illustrate the difference between net and gross SC, consider a utility that operates a nuclear plant. The plant's operating cost of $1.2 \mathrm{k} / \mathrm{kWh}$ makes it very competitive on the spot market, but its high capital cost of $5 \mathrm{k} / \mathrm{kWh}$ makes it uneconomical relative to a new combinedcycle combustion turbine (CCCT). The difference between the utility's $6.2 \notin / \mathrm{kWh}$ cost to own and operate its nuclear plant and the roughly $3.8 \% / \mathrm{kWh}$ cost to own and operate a CCCT could be considered stranded. However, the same utility surely owns some power plants (as well as other assets) that are largely depreciated (e.g., a 30-year-old coal plant). Although these assets may be nearing the ends of their economic lives, their operating lives might be quite long. ${ }^{*}$ This old coal plant, with an operating cost of $1.5 \% / \mathrm{kWh}$ and a capital cost of $1.7 \AA / \mathrm{kWh}$, is very competitive with the combined-cycle unit. Indeed, this coal plant could yield "freed" commitments in a competitive market of $0.6 \mathrm{k} / \mathrm{kWh}$. The point to remember is that a complete assessment of this utility's competitive position should include both the high-cost assets and the low-cost assets.

Feiler (1994) examined the potential liabilities associated with power-purchase contracts. His analysis, based on more than 7300 transactions, "suggests that the potential stranded liability

* Consider a power plant with a 40-year book life and a 20-year tax life. The plant's annual capital cost (depreciation, taxes, interest payments, and shareholder return) in year 20 is less than half of that in year 1. By the 30th year, the annual cost is only $30 \%$ of that in year 1 . 
from above-market, power-purchase contracts for electric utilities is over $\$ 15$ billion annually." Important as this estimate may be, it provides only a partial picture of a utility's vulnerability to increased competition. One must also look at contracts with below-market prices, power plants whose capital and operating costs are below market prices, and so on to gain a complete picture of the utility's situation.

These disparate estimates of SC also reflect very different assumptions. Our analysis, discussed below, suggests that a few assumptions are crucial in determining the magnitude of the SC estimated. These key assumptions concern the fraction of a utility's customers that can exercise choices in selecting alternative power suppliers; the market price of electricity; and the dynamics of a transition from today's vertically integrated, regulated, retail-monopoly-franchise system to some future, more competitive structure. Not surprisingly, these three factors are interdependent. More customers will likely be eligible for choices the longer the transition period considered. The market price of power will likely be directly related to the number of potential customers for competitive electricity. With few buyers (e.g., if only a few large industrial customers are able to leave the local utility system), market prices for those customers may be quite low for several years. On the other hand, if all customers are able to obtain electricity supplies from a competitive marketplace, prices are likely to be much higher (Fig. 1). As Hempling, Rose, and Burns (1994) note:

As a technical matter, estimating [stranded commitments] requires estimating future market prices. No one knows what future market prices will be, for several reasons. The most prominent reason is that no one knows the future industry's structure, because it is being debated now. ... There also is a dynamic nature to the problem. Markets evolve in complex and unpredictable ways. Even if one estimated the future marginal costs of some industry players, one could not estimate how competitors including utilities will respond. Moreover, the playing field will depend on the cumulative effect of numerous government decisions about wholesale competition, retail competition, mergers, future rate design, municipalization, and externalities in prices, to name only a few factors.

Finally, some of the estimates cited above may have ignored the effects of federal and state income taxes. Any losses experienced by utility stockholders are automatically shared with taxpayers. If the average income tax rate is $35 \%$, then utility shareholders pay for only $65 \%$ of the $\mathrm{SC}$.

To illustrate the effects of income taxes, consider the situation shown in Table 1. The utility sells $23,552 \mathrm{GWh}$ in a particular year at a price of $7.21 \mathrm{c} / \mathrm{kWh}$ (the utility's price of $7.00 \% / \mathrm{kWh}$ plus a $3 \%$ sales tax). As shown in the second column, the utility's net income in this case is $\$ 187.4$ million. If, because of competitive forces, the utility cuts its price by $10 \%$ (to $6.30 \notin / \mathrm{kWh}$ plus the $3 \%$ sales tax), its revenue is cut by the same $10 \%, \$ 170$ million. However, this $\$ 170$ million revenue reduction is partially offset by a sales-tax reduction of $\$ 5$ million plus 
an income-tax reduction of $\$ 59$ million. The income-tax reduction is a function of the utility's $36 \%$ income-tax rate, and the sales-tax reduction is a function of its $3 \%$ sales-tax rate. Thus, the shareholder loss is $64 \%(100 \%-36 \%)$ of the net revenue loss to the utility $\{\$ 105 /[\$ 170 *(100$ $-3 \%)]\}$.

MARKET-CLEARING PRICE ( $\$ / k W h)$

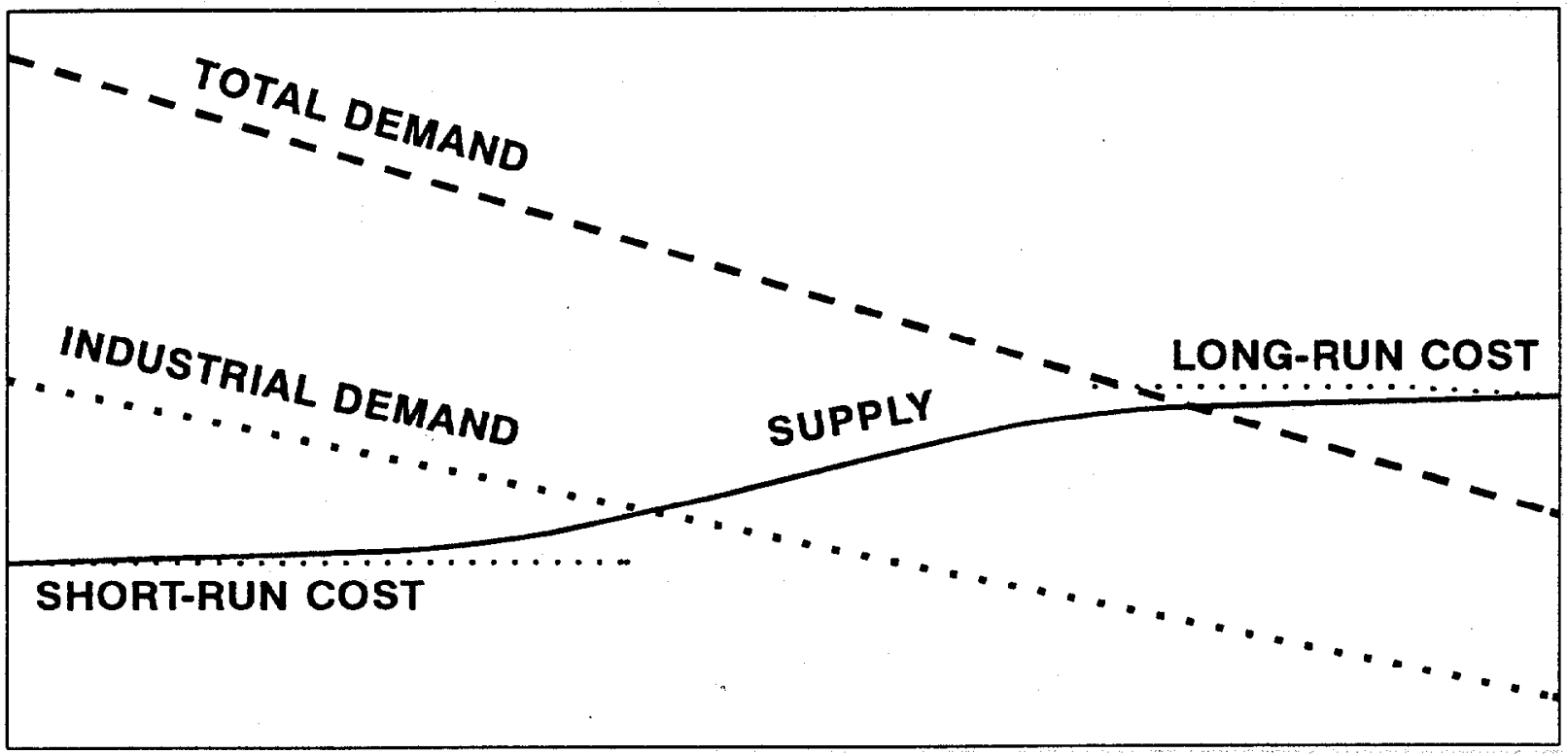

QUANTITY (MWh)

Fig. 1. Relationships between supply and demand in determining the market price for electricity. At low levels of demand, the supply price will likely be close to the short-term operating cost of existing power plants. At high levels of demand, the price will approximate the capital plus operating cost of new power plants, assumed here to be gas-fired combined-cycle units. 
Table 1. The effects of income taxes on transforming revenue changes into changes in net income

\begin{tabular}{|c|c|c|c|}
\hline \multirow{2}{*}{$\begin{array}{l}\text { Income statement } \\
\text { items }\end{array}$} & \multicolumn{2}{|c|}{ Amount (million \$) } & \multirow[b]{2}{*}{ Comments } \\
\hline & $\begin{array}{l}\text { Base } \\
\text { case }\end{array}$ & $\begin{array}{c}\text { Price cut } \\
10 \%\end{array}$ & \\
\hline Electric revenues & $1,698.1$ & $1,528.3$ & Cut revenues $\$ 170$ million \\
\hline \multicolumn{4}{|l|}{ Expenses } \\
\hline Fuel & 381.8 & 381.8 & \\
\hline Purchased power & 124.4 & 124.4 & \\
\hline O\&M, fixed + variable & 124.9 & 124.9 & \\
\hline Production expenses, total & 631.2 & 631.2 & \\
\hline Nonproduction expenses & 320.7 & 320.7 & \\
\hline Book depreciation & 157.9 & 157.9 & \\
\hline Revenue sensitive taxes & 50.9 & 45.8 & Sales tax cut $\$ 5$ million \\
\hline Property taxes & 75.7 & 75.7 & \\
\hline Federal income taxes, current & 105.4 & 46.1 & Income taxes cut $\$ 59$ million \\
\hline Federal income taxes, deferred & 0.0 & 0.0 & \\
\hline Expenses, total & $1,341.8$ & $1,277.4$ & \\
\hline Operating income & 356.3 & 250.8 & \\
\hline Interest expense & 168.9 & 168.9 & \\
\hline Net Income & 187.4 & 82.0 & Net income cut $\$ 105$ million \\
\hline Dividends & 140.5 & 61.5 & \\
\hline Additions to retained earnings & 46.8 & 20.5 & \\
\hline
\end{tabular}




\section{ALTERNATIVE WAYS TO COMPUTE STRANDED COMMITMENTS}

San Diego Gas \& Electric (1994) categorized methods to calculate SC along three dimensions: bottom-up vs top-down, ex ante vs ex post, and administrative vs market determination (Table 2).

Table 2. Alternative ways to compute stranded commitments

\begin{tabular}{lccccc}
\hline & \multicolumn{2}{c}{ Administrative valuation } & & \multicolumn{2}{c}{ Market valuation } \\
\cline { 2 - 5 } & Ex ante & Ex post & & Ex ante & Ex post \\
\hline $\begin{array}{l}\text { Bottom- } \\
\text { up }\end{array}$ & $\begin{array}{c}\text { Asset-by-asset } \\
\text { value projections }\end{array}$ & $\begin{array}{c}\text { Assets valued } \\
\text { after restructuring }\end{array}$ & $\begin{array}{c}\text { Assets sold at } \\
\text { auction }\end{array}$ & $\begin{array}{c}\text { After-the-fact } \\
\text { purchase-price } \\
\text { adjustment }\end{array}$ \\
$\begin{array}{llll}\text { Top- } \\
\text { down }\end{array}$ & $\begin{array}{c}\text { Projection of } \\
\text { regulated rate by } \\
\text { customer class }\end{array}$ & $\begin{array}{c}\text { After-the-fact } \\
\text { adjustment of } \\
\text { regulated prices }\end{array}$ & $\begin{array}{c}\text { Bundles of assets } \\
\text { spun off }\end{array}$ & $\begin{array}{c}\text { Deferred } \\
\text { valuation of spun- } \\
\text { off assets }\end{array}$ \\
\hline
\end{tabular}

Source: San Diego Gas \& Electric (1994).

To illustrate, a bottom-up, ex ante, administrative approach would involve calculation of the unit-by-unit performance of each of a utility's power plants in a hypothesized competitive generation market. Calculating the return provided by each generating unit involves detailed production-cost simulations for both the utility in question and the surrounding utilities and independent power producers. These simulations would show the number of hours each year that each unit operates, the market price of power that hour, and, from these numbers, the profitability of each unit. Such calculations require thousands of assumptions concerning present and future customer locations, loads, load shapes, and peak loads; transmission system operation, expansion, constraints, costs, and pricing rules; operating costs and performance of all existing and new generating units; fuel prices; government decisions on siting and environmental restrictions for new power plants and transmission lines; and so on. A bottom-up analysis requires similarly detailed calculations of stranded liabilities, regulatory assets, and public-policy programs. As San Diego Gas \& Electric (1994) put it, "The essence of the [bottom-up] method is to work asset by asset [as well as liability by liability] to identify a market price and compare this price with the regulated cost of the asset [or liability]." 
The top-down approach is the opposite of the bottom-up approach. The top-down approach, rather than using the individual asset as the unit of observation, treats the utility as the unit of observation. In the top-down, ex ante, administrative approach, which is the one we apply later, the embedded cost of electricity from each utility is compared with an assumed market price. This approach is much simpler than the bottom-up approach, primarily because it requires only a few assumptions and elementary calculations. However, it is also much less detailed and, therefore, provides fewer insights into the specific assets, liabilities, and costs that account for a utility's SC situation.

An ex ante approach determines the amount of stranded commitment before the transition to competition is conducted. An ex post approach determines the amount stranded after the transition is complete, based on actual market conditions. Although not explicit in the San Diego classification system, the ex ante approach is closely related to regulatory determination of the amount of SC, while the ex post approach is closely related to market determinations. To illustrate an ex ante approach, a state regulatory commission might conduct hearings to determine the amount and allocation of SC before approving a new industry structure (California Public Utilities Commission 1994). Alternatively, in an ex post approach, the commission could order a new structure in which the local utility sells all its power plants. The market price of these assets could then be compared to their book value in later determining the amount and allocation of SC.

Administrative determination involves agreement between the utility and the regulator (presumably the state public utility commission but, in some cases, the Federal Energy Regulatory Commission) on the amount that is stranded (FERC 1994). Market determination relies on the purchase price of various assets to determine how much is stranded.

The dollar value computed with any of these methods will depend on various factors, including the timing and scope of the transition to competition. If the transition occurs rapidly and affects all customer classes, the stranded costs will be much greater than if the transition occurs gradually over several years. The structure of the generation market and treatment of present and future power-purchase contracts will also affect the dollar estimates. Whether utilities can write up some or all of the value of their transmission assets (to offset losses associated with uneconomical generation assets) will affect the estimated costs of SC (Moskovitz and Foy 1994).

We found several recent analyses that used these alternative ways to compute SC. Anderson, Graham, and Hogan (1993) used a bottom-up method to calculate SC as a function of market prices for electricity. They computed the exposure associated with stranded assets (coal and nuclear power plants) for the Pennsylvania-New Jersey-Maryland (PJM) power pool as \$11 billion for 1998 to 2002. This exposure is approximately equal to the utilities' book equity. This estimate is large because Anderson et al. assumed that the utilities would receive revenue only "from the marginal energy charge" with no capacity payments. In other words, utilities receive enough money to cover only variable (fuel plus operations and maintenance) costs, with no recovery of fixed costs. 
Merrill Lynch (1994) used a top-down method to develop a competitive-risk matrix for electric utilities, based in part on the difference in industrial electricity price for a utility and the regional average price. McCullough and Brown (1994) calculated the amount of price increases that residential and commercial customers would face if industrial customers could purchase power at a price defined by a gas-fired CCCT. Moody's (1994), using a bottom-up approach, estimated the competitiveness of individual power plants in what it called the "Michigan Competitive Arena" an area that includes 13 investor-owned utilities (IOUs) in Michigan, Indiana, Ohio, Kentucky, and Illinois. Moody's calculated a market-clearing price and then calculated the margins (either positive or negative) that each plant would receive in that market. Rudden Associates (1994) used a bottom-up approach similar to the one used by Moody's to calculate marginal costs for generation in each North American Electric Reliability Council (NERC) region and subregion, using these market costs to determine the competitiveness of individual generating units.

Filings with the California Public Utilities Commission showed the diversity of approaches used to calculate $\mathrm{SC}$ and the range of results that can therefore occur. Pacific Gas and Electric (1994) calculated SC using "as a proxy for market prices, a range of $4 \notin / \mathrm{kWh}$ plus or minus $20 \%$ for baseload generation." The company calculated SC assuming that the costs of utility-owned generation, qualifying-facility power-purchase obligations, and regulatory assets would be recovered over 6,9 , or 12 years. These costs ranged from $\$ 3$ to 16 billion. The PUC's Division of Ratepayer Advocates and the Center for Energy Efficiency and Renewable Technologies, on the other hand, challenged many of the utility assumptions and developed estimates of SC that were much lower. Indeed, the Division of Ratepayer Advocates recommended a value of zero (Goldman and Belden 1994). These differences hinged on use of net vs gross SC; assumptions concerning market prices, utility costs, and the size of the markets at risk from competition; and the extent to which the utility could mitigate what would otherwise be SC. 


\section{ORNL METHOD}

We developed and applied a top-down method to estimate the amounts of SC faced by individual IOUs. It is similar in principle to the methods developed by Merrill Lynch (1994) and by McCullough and Brown (1994).

Our method is based on the difference between the industrial electricity price for the utility in question and an estimated market price for the region as a whole. We tested two proxies for market price: (1) the capital and operating cost of a CCCT" and (2) a "capacity-adjusted" price that lies between the region's short-term operating cost and the cost of a CCCT based on the capacity margin in the region. We assume that this latter price equals the region's short-term operating cost if the region's capacity margin exceeds $20 \%$, equals the region's cost of a CCCT if the region's capacity margin is below $15 \%$, and varies linearly between these two levels for capacity margins between 15 and $20 \%$.

For purposes of sensitivity analysis, we also tested two other prices: the average industrial electricity price in the region and the short-term operating cost of existing power plants. (The assumed short-run marginal cost is $2 \notin / \mathrm{kWh}$ in each region.) The market price declines, and therefore the estimates of SC increase, as one moves from the industrial price to the short-term operating cost. Appendix Table A-1 shows the four sets of regional prices, and Table A-2 shows the details of CCCT capital and operating costs.

We used the nine NERC regions to define the boundaries of competitive electricity markets (Fig. 2). Although electricity flows across these boundaries, they seem like reasonable limits given the coordination and planning that occurs within each region.

We tested two assumptions concerning the fraction of a utility's retail load that would be at risk (i.e., able to obtain electricity supplies from a competitive regional market): (1) industrial customers only or (2) all retail customers. These alternatives probably bound the range of likely outcomes.

In both cases, we used the difference between the utility's average industrial price and the assumed regional market price as the relevant measure of SC. Industrial prices typically include

*For the industrial-only case, we assumed a capacity factor of $75 \%$; for the all-retail case we assumed a capacity factor of $60 \%$ (Table A-2). These assumptions reflect the difference in load factors between the industrial class and other retail classes. 
generation and transmission costs but no distribution-system costs and few customer-service costs. Thus, industrial price is a good proxy for the utility's ability to compete in wholesale markets. On the other hand, prices to residential and commercial customers include substantial costs not related to generation and transmission. Comparing prices that include many services with a generation-and-transmission-only market price would be inappropriate.

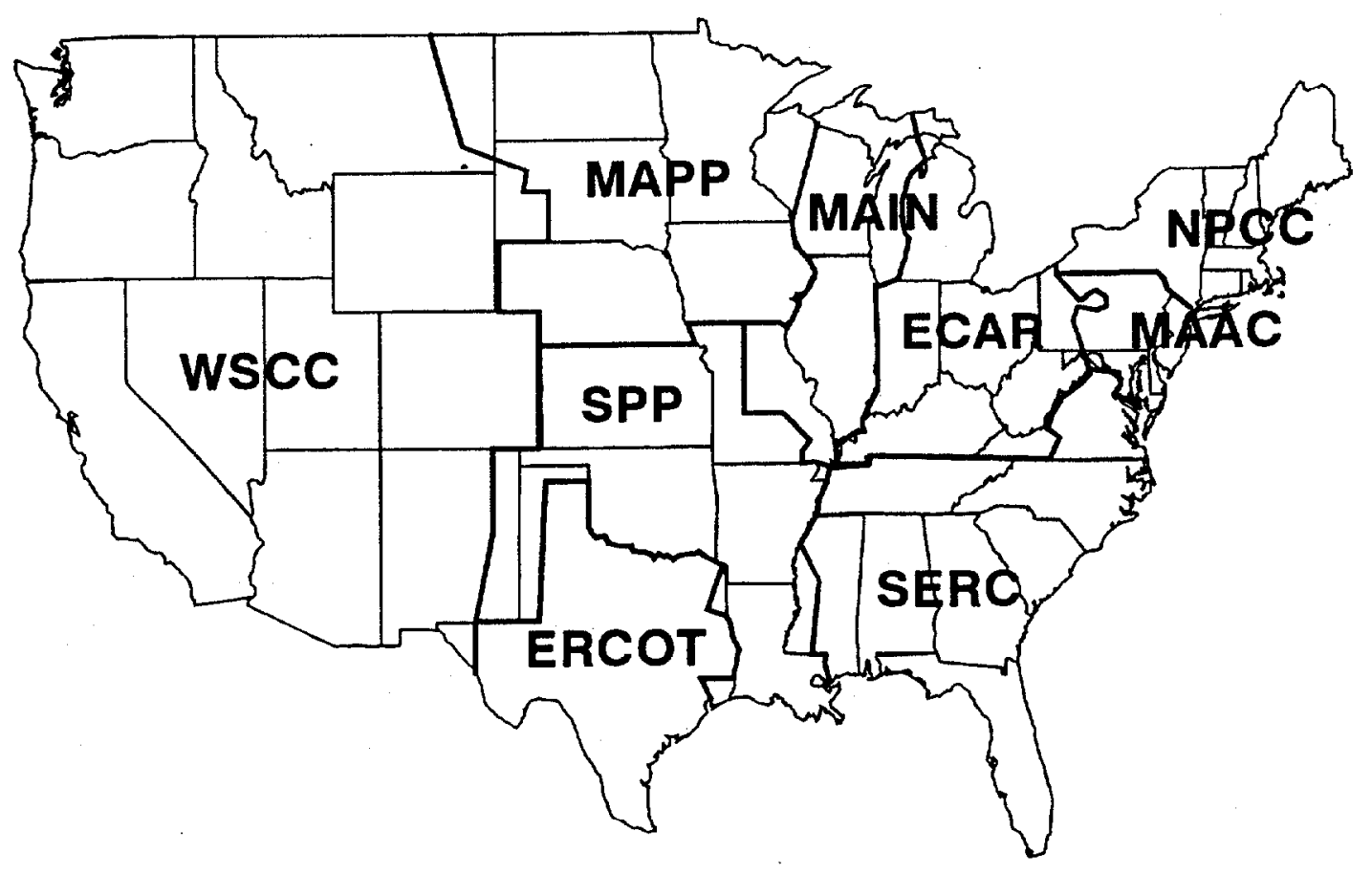

Fig. 2. Map of the United States showing the approximate boundaries of the nine NERC regions.

We added $0.44 \notin / \mathrm{kWh}$ to the regional market prices to make them consistent with the utility's average industrial rate. ${ }^{*}$ In a competitive environment, transmission owners will likely try to charge higher prices. For example, Detroit Edison's retail wheeling tariff proposes a charge of about 2.0ф/kWh for transmission and ancillary services (Musial 1994). ${ }^{\#}$

Our method also requires assumptions concerning the number of years during which the price difference noted above persists, the appropriate discount rate to use in calculating the net present value (NPV) of this revenue loss, and the combined federal-state income tax rate.

"This estimate is based on the 1992 embedded cost of transmission averaged over all large IOUs (EIA 1993). Transmission accounts for $6.2 \%$ of total utility costs, with costs allocated among generation, transmission, distribution, and customer service. The national average retail electricity price for all IOUs was $7.12 \notin / \mathrm{kWh}$ in 1993 (EEI 1994). Then 0.062(7.12) =0.44€/kWh.

\#The Michigan Public Service Commission (1994), commenting on the "wide disparity in pricing" of transmission services, cited estimates of transmission and other wheeling costs ranging from 0.4 to $4.2 \mathrm{k} / \mathrm{kWh}$. 
To illustrate our method, consider a utility whose industrial customers are free to choose alternate suppliers. If the utility's average industrial price exceeded the regional market price, that utility would have to cut its price to all industrial customers to the market price to maintain market share. In other words, the utility's annual revenues would be cut by the product of its industrial sales and this difference in electricity price. If this difference persists unchanged (in constant-dollar terms) for ten years, then the amount of SC would equal the net present value of the after-tax ten-year revenue loss. During this time, the utility would likely reduce its costs (e.g., by cutting staff and renegotiating fuel-supply and power-purchase contracts). In addition, depreciation would reduce the amount of uneconomical (i.e., expensive) capacity that the utility has on its books. We ignore these possibilities.

We used data for 1992 and 1993 that utilities report to the Energy Information Administration on EIA-861 and to the Federal Energy Regulatory Commission (FERC) on FERC-1(EIA 1994a and Edison Electric Institute 1994). These data include retail sales, revenues, and prices by customer class, as well as the utility's equity [specifically, the value of its common stock, preferred stock, retained earnings, and several smaller items, which in total are called total proprietary capital (EIA 1993)].

The 160 utilities included in our database account for virtually all of the 1992 industrial sales and revenues by the 180 major IOUs included in the EIA (1993) report. We used the Electric Power Research Institute's Technical Assessment Guide to calculate the cost of a combined-cycle unit (EPRI 1993); see Table A-2. We used state-level data on the prices that electric utilities paid for natural gas to compute the operating cost of a CCCT for each NERC region (Edison Electric Institute 1993). And we used projections developed by the North American Electric Reliability Council (1994) of capacity margins to the year 2003 (Table A-13).

We calculated market electricity prices for each of the nine NERC regions in the contiguous United States (Figs. 2 and 3). We then compared the values of industrial electricity price and the regional average for each of the 160 major IOUs in our database. Thus, we assume that competition is much more likely within each region than between regions. If the utility's price exceeded the regional average, we computed an annual revenue loss as:

Revenue loss $(\$ /$ year $)=\Delta$ Industrial price $(\$ / \mathrm{kWh}) \times$ Industrial sales $(\mathrm{GWh} /$ year $)$, where $\Delta$ Industrial price $=0$ if $P_{\text {utility }}<P_{\text {region }}$ and $=P_{\text {utility }}-P_{\text {region }}$ if $P_{\text {utility }}>P_{\text {region }}$.

We assumed that this revenue loss (in real dollars) would persist for ten years. We computed the NPV of this annual loss for the ten-year period with a real discount rate of $8 \%$. This discount rate is equivalent to a return on equity of 11 to $12 \%$ and an annual inflation rate of 3 to $4 \%$. Our assumed return on equity is consistent with current figures compiled by Merrill Lynch (Cohen et al. 1994). Finally, we reduced the amount of this loss because taxpayers (through federal and income taxes) would pay for about $35 \%$ of these totals. In Chapter 5, we present 
sensitivity analyses, in which we varied the discount rate, the number of years, the competitivemarket price (up or down from the NERC-region average), and the share of retail load at risk.

1993 REGIONAL ELECTRICITY PRICE ( $₫ / \mathrm{kWh})$

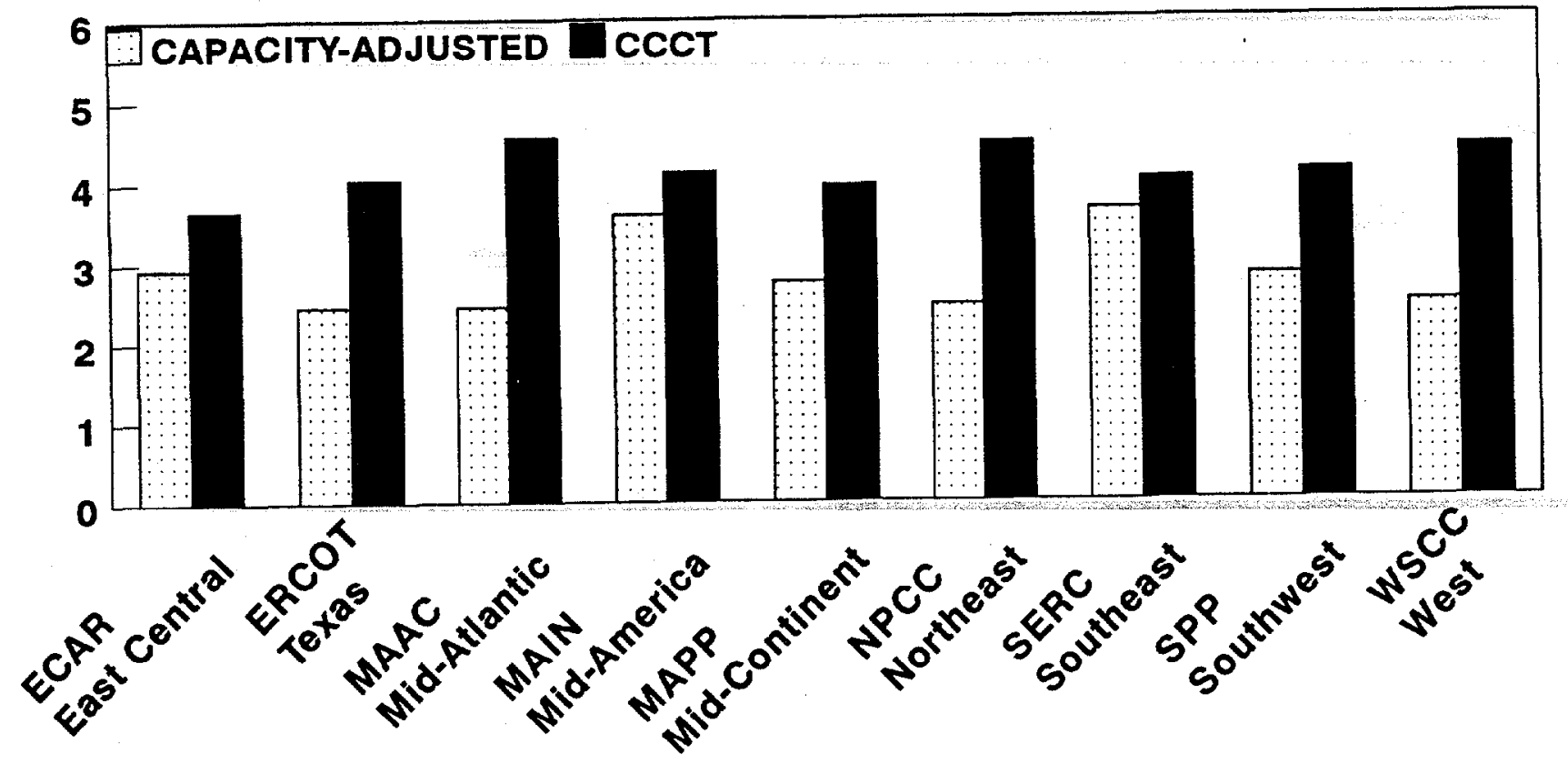

Fig. 3. Alternative estimates of regional market electricity prices by NERC region. (See Table A-1 for details on all four sets of assumed regional market prices.) 


\section{RESULTS}

Among individual utilities, industrial prices in 1993 ranged from less than $2 \notin / \mathrm{kWh}$ to more than $10 \notin / \mathrm{kWh}$. Across the nine NERC regions, average industrial prices ranged from $4.2 \notin / \mathrm{kWh}$ in MAPP to $7.4 \notin / \mathrm{kWh}$ in NPCC. The regional variation in CCCT prices was less, ranging from $3.6 \notin / \mathrm{kWh}$ in ECAR to $4.6 \% / \mathrm{kWh}$ in MAAC (Fig. 3). And the capacity-adjusted price, ranged from $2.4 \notin / \mathrm{kWh}$ in ERCOT, MAAC, NPCC, and WSCC (where capacity margins are all above $20 \%$ ) to $3.6 \% / \mathrm{kWh}$ in MAIN and SERC (where capacity margins are only about $16 \%$ ). Because of these large price differences, both across individual utilities and across regions, a substantial amount of revenue could be "lost" for those utilities with prices higher than the regional market price.

The results presented below assume that the revenue loss continues unchanged in real dollars for ten years with the NPV of the revenue loss calculated at a real discount rate of $8 \%$.

Consider first the industrial sector only. As the assumed market price of power declines from the regional industrial price to the CCCT price, capacity adjusted price, and the short-run marginal cost, the amount of SC increases (Table 3), ranging from $8 \%$ to $45 \%$ of the equity held by all the major U.S. IOUs. To take what we consider to be a reasonable example, consider the case where industrial customers can obtain electricity at the capacity-adjusted price (Table A-3). Overall, $77 \%$ of U.S. IOU industrial sales would be affected, equivalent to $711,000 \mathrm{GWh} / \mathrm{year}$, leading to an annual revenue loss of $\$ 15.8$ billion. The NPV of the associated after-tax earnings loss is $\$ 68.8$ billion, which represents $38 \%$ of IOU equity.

If all retail customers (residential, commercial, and industrial) are able to obtain electricity at market prices, the amounts of stranded commitment are larger, ranging from $21 \%$ to $140 \%$ of utility equity (Table 3 ). However, as noted above, we think it is unrealistic to match a large demand with a very low price (and vice versa). Thus, we think that competition that allows only the industrial class to access competitive generation markets will yield low market prices (i.e., the right side of the Industrial-only line in Table 3). On the other hand, if industry restructuring allows all retail customers to obtain market-priced power, that price will be higher (i.e., the left side of the All-retail line in Table 3). For the case with all retail load at risk and the market price based on the cost of a CCCT, SC amounts to $\$ 99$ billion for the ten years, equivalent to $54 \%$ of IOU equity (Table A-8). 
These results suggest that utilities might be at risk for 38 to $54 \%$ of their equity, based on the industrial-only/capacity-adjusted price and the all-retail/CCCT price cases. These two cases show substantial differences across NERC regions (Fig. 4).

Table 3. Potential stranded commitment in billions of 1992 dollars (and as percent of equity) as a function of portion of load at risk and market price of generation

\begin{tabular}{lcccc}
\hline & \multicolumn{4}{c}{ Market price } \\
\cline { 2 - 6 } $\begin{array}{l}\text { Portion of } \\
\text { load at risk }\end{array}$ & $\begin{array}{c}\text { Industrial } \\
\text { average }\end{array}$ & $\begin{array}{c}\text { Combined-cycle } \\
\text { turbine }\end{array}$ & $\begin{array}{c}\text { Capacity } \\
\text { adjusted }\end{array}$ & $\begin{array}{c}\text { Short-run } \\
\text { marginal cost }\end{array}$ \\
\hline Industrial only & $15(8 \%)$ & $34(19 \%)$ & $69(38 \%)$ & $83(45 \%)$ \\
All retail & $39(21 \%)$ & $99(54 \%)$ & $210(115 \%)$ & $256(140 \%)$ \\
\hline
\end{tabular}

${ }^{2}$ The assumed market prices decline from left to right.

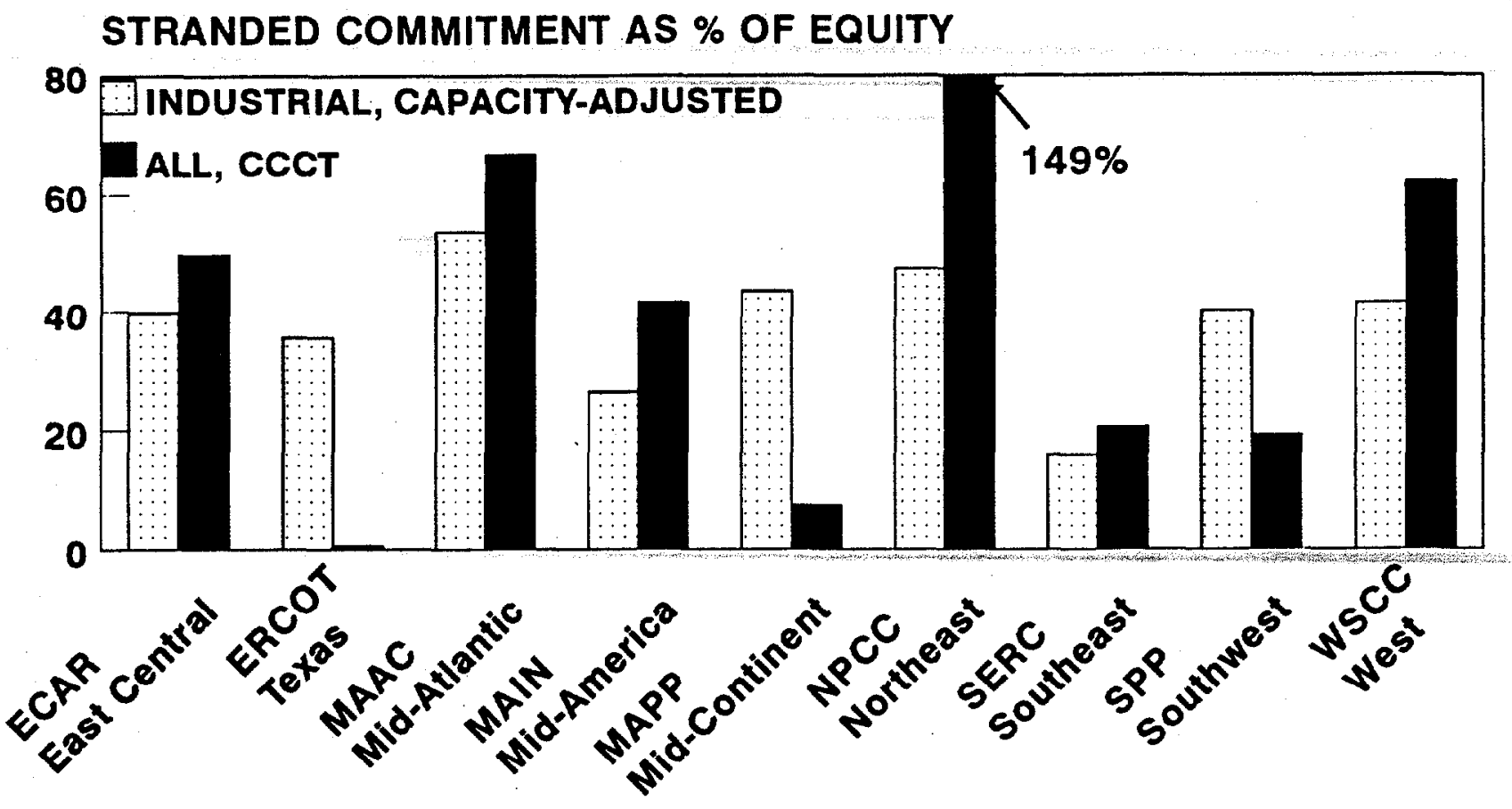

Fig. 4. Potential stranded commitments normalized by equity for the nine NERC regions in the contiguous United States. (Tables A-3 and A-8 show the details for these two cases.)

For the industrial-only/capacity-adjusted-price case (dotted bars in Figs. 3 and 4), losses are highest in MAAC (54\% of IOU equity would be stranded with these assumptions) and lowest in SERC (16\%). The market price in MAAC (as well as in ERCOT, NPCC, and WSCC) is quite low because of high capacity margins (Tables A-1 and A-13). This low market price combined 
with the high industrial prices of many utilities in MAAC (as well as in NPCC) leads to large losses (Table A-3). On the other hand, the market price in SERC is high because capacity margins in that region are low. And industrial prices are low in SERC, further reducing the SC in this case.

Altogether, 153 utilities (of the 160 IOUs examined) face some SC in this case. Of these, 17 have SC that exceed $100 \%$ of their equity, and another 120 have SC between 10 and $100 \%$ of equity. Twenty utilities have potential losses of $\$ 1$ billion or more. These utilities are concentrated in a few states, including California, Pennsylvania, Texas, New York, and Ohio in declining order of importance. Losses exceed $50 \%$ of utility equity in 13 states (left side of Table 4).

Table 4. States in which stranded commitments might exceed $50 \%$ of utility equity

\begin{tabular}{|c|c|c|c|}
\hline \multicolumn{2}{|c|}{$\begin{array}{c}\text { Industrial only, } \\
\text { Capacity-adjusted price }\end{array}$} & \multicolumn{2}{|c|}{$\begin{array}{c}\text { All retail, } \\
\text { Combined-cycle price } \\
\end{array}$} \\
\hline State & $\begin{array}{c}\% \text { of equity } \\
\text { stranded }\end{array}$ & State & $\begin{array}{l}\% \text { of equity } \\
\text { stranded }\end{array}$ \\
\hline Rhode Island & 142 & Rhode Island & 405 \\
\hline Maine & 113 & Massachusetts & 230 \\
\hline New Hampshire & 109 & New Hampshire & 179 \\
\hline Massachusetts & 71 & Connecticut & 170 \\
\hline Nevada & 62 & New York & 139 \\
\hline Arkansas & 58 & Maine & 119 \\
\hline Pennsylvania & 56 & New Jersey & 117 \\
\hline Minnesota & 55 & California & 99 \\
\hline Connecticut & 55 & Mississippi & 97 \\
\hline California & 53 & Michigan & 88 \\
\hline Maryland & 52 & Arizona & 76 \\
\hline Michigan & 52 & Arkansas & 63 \\
\hline \multirow[t]{4}{*}{ Louisiana } & 51 & Illinois & 61 \\
\hline & & Ohio & 60 \\
\hline & & New Mexico & 60 \\
\hline & & Pennsylvania & 52 \\
\hline
\end{tabular}

For the all-retail/CCCT price case (solid bars in Figs. 3 and 4), the total amount of SC is larger than for the industrial-only/capacity-adjusted price case considered above ( 54 vs $38 \%$ of equity). By far, the largest losses occur in NPCC (149\% of equity). Losses are less than 10\% in 
ERCOT and MAPP. The potential losses are so large in NPCC because the retail load at risk is much larger than in most regions and because the industrial price is the highest among all regions (Table A-8). Losses are low in ERCOT and MAPP because both industrial prices and the amount of load at risk are low.

Altogether, 100 utilities face some SC in this case. Of these, 36 have SC that exceed $100 \%$ of their equity, and another 53 have SC between 10 and $100 \%$ of equity. Twenty-five utilities have potential losses of $\$ 1$ billion or more. These utilities are concentrated in a few states, including New York, California, New Jersey, Massachusetts, Ohio, and Pennsylvania in declining order of importance. Lost revenues exceed $50 \%$ of utility equity in 16 states (right side of Table 4).

Estimates of SC losses are higher for the all-retail case than for the industrial-only case, as expected, in six of the nine NERC regions (Fig. 4). SC losses are higher in the industrial-only case for the other three regions. In ERCOT, the amount of sales "lost" in the all-retail case is very small because the industrial price for most utilities is below that of the CCCT, although far above that of the capacity-adjusted price. In MAPP, the amount of sales lost is about the same in both cases, but the price difference is much greater in the industrial-only case. And in SPP, the amount of sales lost is greater in the all-retail case, but the price difference is so much larger in the industrial-only case that the SC losses are greater in the latter case.

In both cases, the potential SC losses are especially severe in California, New York, Ohio, and Pennsylvania. Relative to the amount of utility equity, losses could be largest in several New England states (Maine, Massachusetts, New Hampshire, and Rhode Island).

As noted earlier, the amount of SC depends strongly on the assumptions made. The key assumptions are the market price of electricity and the fraction of retail load lost. Figure 5 shows the importance of these factors. At any market price, the loss to utility shareholders is 2.5 to 3 times as great when all retail loads are at risk than when only industrial loads are at risk. Raising the assumed market price of electricity by $1 \mathrm{c} / \mathrm{kWh}$ decreases the equity loss by 25 percentage points for all retail customers and by 10 percentage points for the industrial class only. Lowering the market price by $1 \notin / \mathrm{kWh}$ increases the equity loss by 33 and 14 percentage points, respectively. ${ }^{*}$ For the all-retail case, the change in stranded commitments is about $\$ 60$ billion for every $1.0 \% / \mathrm{kWh}$ change in the market price of electricity. (Tables A-6 and A-7 show detailed results for cases in which industrial sales are at risk and the market price is the capacity-adjusted price $\pm 1 \notin / \mathrm{kWh}$. Tables A-11 and A-12 show detailed results for cases in which all retail sales are at risk and the market price is the CCCT price $\pm 1 \not / \mathrm{kWh}$.)

*This asymmetry occurs because the amount of SC depends on the difference between the utility's price and the market price, but only if the utility's price is above the market price. A $1 \varnothing / \mathrm{kWh}$ increase in market price, for example, would reduce both the price difference and the number of utilities that face SC in a nonlinear fashion. 
STRANDED COMMITMENT AS \% OF EQUITY

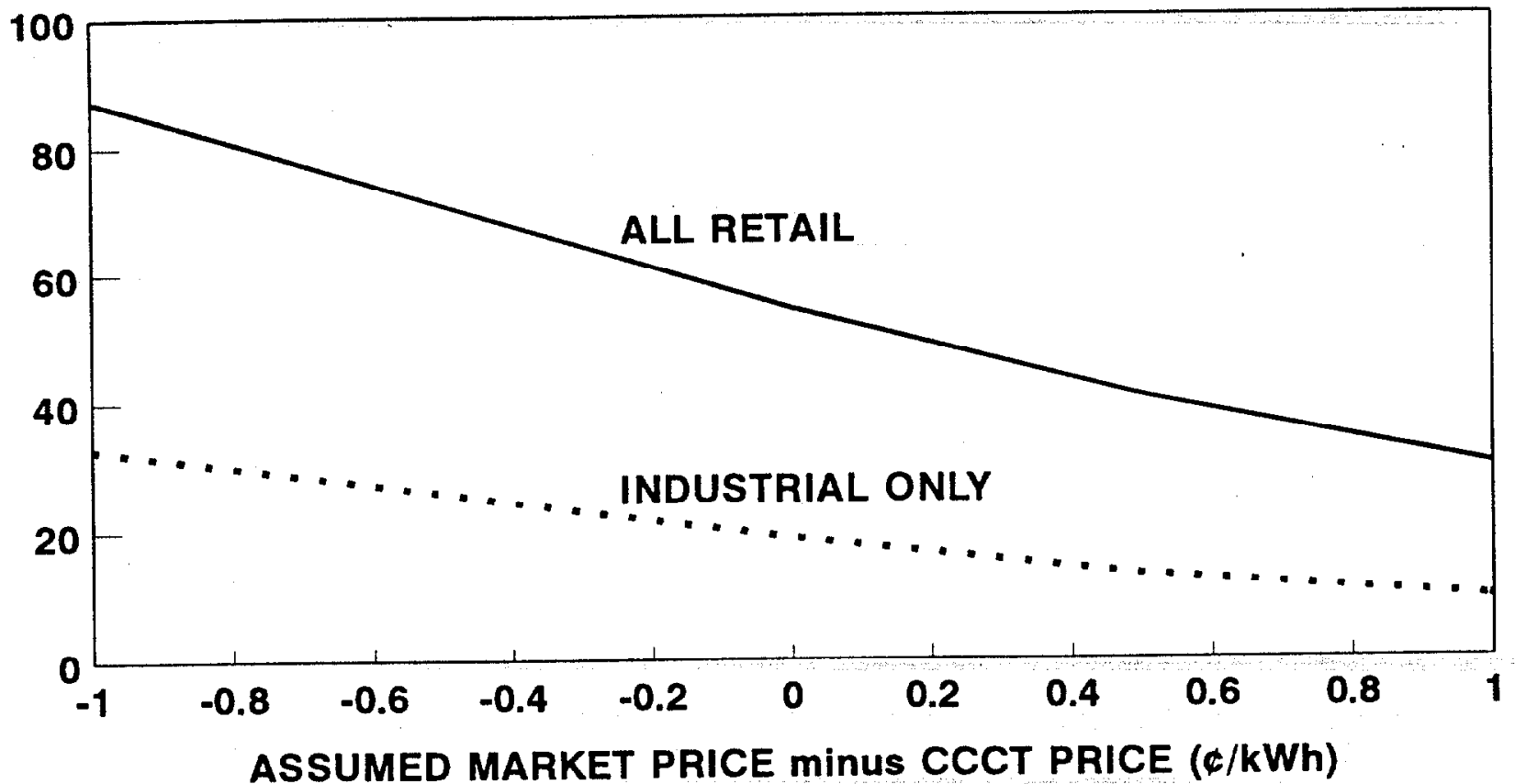

Fig. 5. Amount of stranded commitment for U.S. investor-owned electric utilities as a function of assumed market price (relative to the cost of a combined-cycle unit) and the amount of retail load at risk.

STRANDED COMMITMENT AS \% OF EQUITY

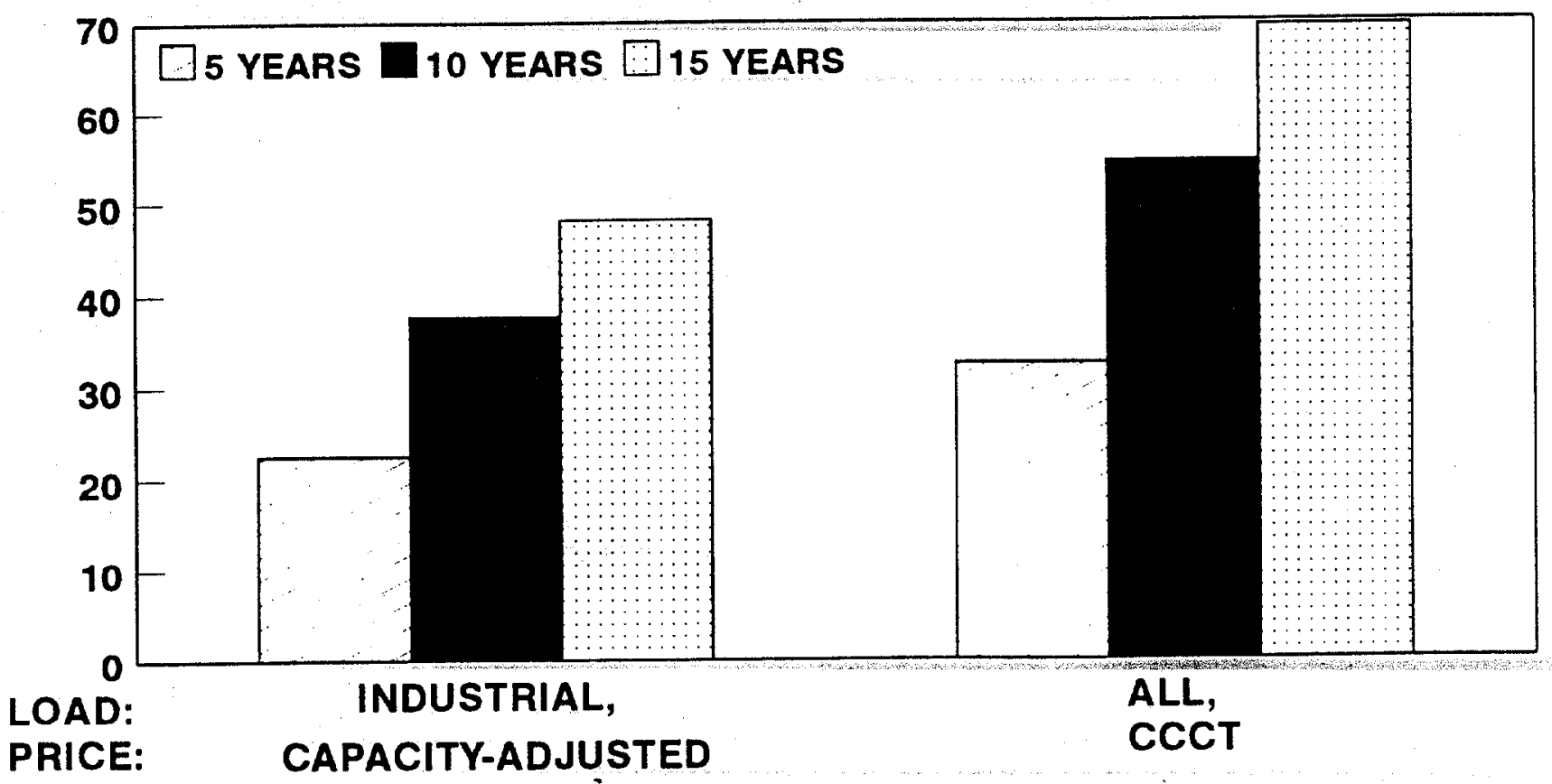

Fig. 6. Amount of stranded commitment for U.S. investor-owned electric utilities as a function of the years of loss and the amount of retail load at risk. 
Another key assumption that affects results is the number of years over which the utility loses this revenue. If the revenue loss would occur for only five years (rather than the ten years assumed above), the equity loss would be cut by $40 \%$ (Fig. 6). On the other hand, if the revenue loss were to occur for 15 years, then the equity loss would increase by almost $30 \%$. The asymmetry around ten years is a consequence of discounting. (Tables A-3 through A-5 show details for the cases in which industrial sales are at risk for 10,15 , or 5 years. Tables A-8 through A-10 show the comparable cases in which all retail sales are at risk.

Next, we varied the discount rate to see its effect on estimates of SC. Decreasing the real discount rate from 8 to $5 \%$ increases the amount of SC by $15 \%$, while increasing the discount rate to $11 \%$ cuts the amount of SC by $12 \%$. These results show that the discount rate has less effect on results than does the number of years that the lost revenues occur. Both factors are less important than the market price and fraction of retail load able to obtain market-priced electricity.

Finally, we ran a case in which the fraction of utility retail markets at risk, the market price of power, and utility prices all vary from year to year. Specifically, we assumed that in 1993 all industrial customers were free to choose their suppliers. For the next four years, increasing fractions of the remaining retail customers are offered such choices so that in 1997 all retail customers have access to alternate suppliers. We assumed that the utility, through vigorous costcutting efforts, is able to reduce its industrial electricity price each year by $2 \%$ of the 1993 price. We assumed that natural gas prices increase linearly by $2 \%$ of the regional 1993 price. Finally, we assumed that the capacity-adjusted price that industrial customers face increases as capacity margins decrease from year to year (Table A-13). These assumptions yield national estimates of $\mathrm{SC}$ that first increase while the share of retail sales that is eligible grows and then declines from year to year, as shown in Fig. 7. The earnings loss in 1994 and 1995 is $\$ 10.9$ billion, declining to only $\$ 1.1$ billion in the year 2009. The NPV of these losses is about $\$ 66$ billion, which is within the range of results presented above (Table 3). 
ANNUAL EARNINGS

LOSS (billlon 1992-\$)
NPV OF LOSS

(billion 1992-\$)

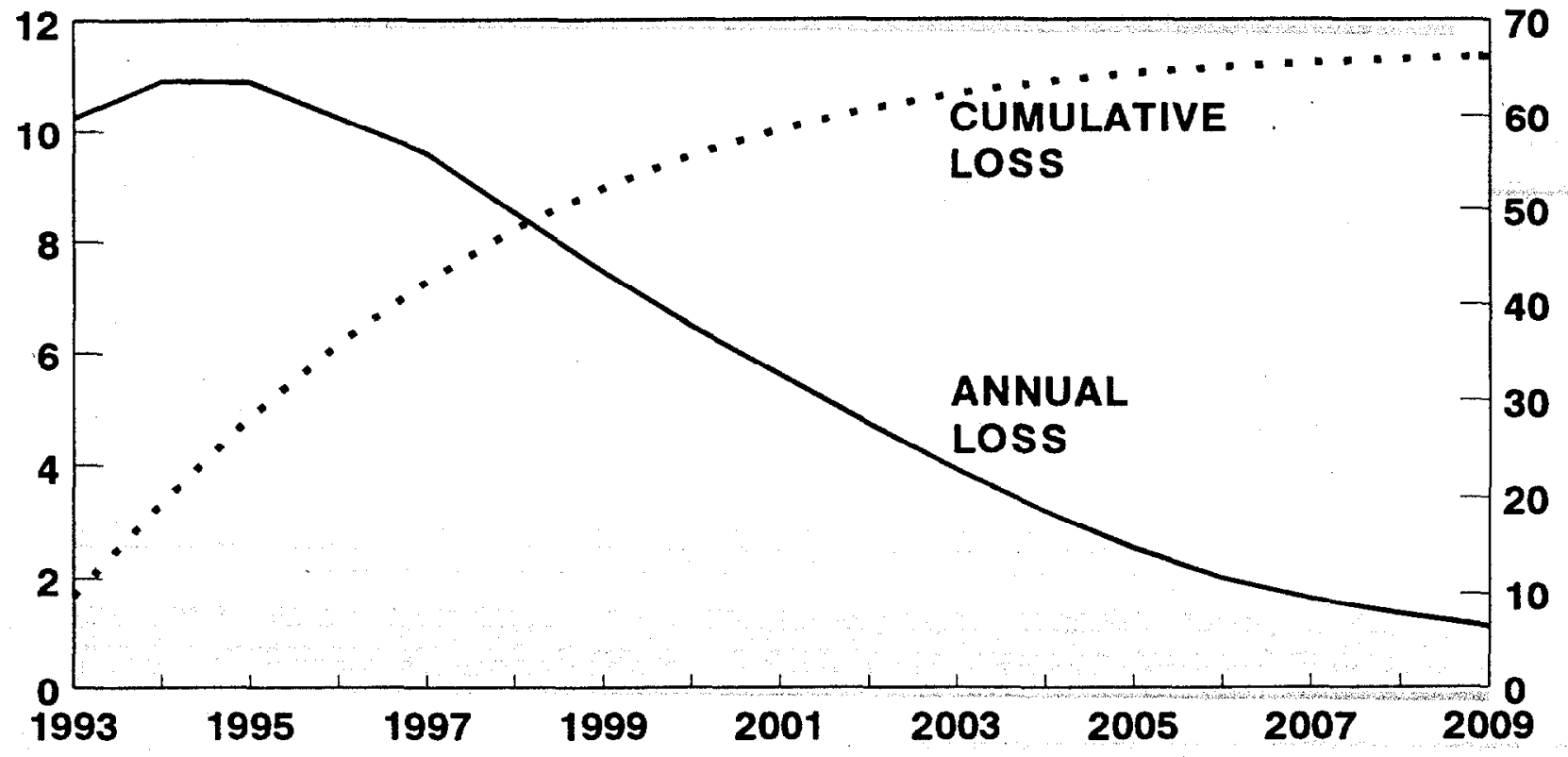

Fig. 7. Annual and cumulative earnings losses for U.S. electric utilities over time assuming dynamic changes in retail markets at risk, the market price of electricity, and utility costs. 


\section{OUR ASSUMPTIONS AND THEIR VALIDITY}

Our method for calculating stranded commitment is very simple. It ignores all the details of the capital and operating costs of individual power plants, the differences in state and local taxes across utilities, customer load shapes and locations, and transmission and distribution costs, as well as many other factors. Our approach is a simple top-down method that abstracts from all these details.

Our key assumptions are:

That this static analysis captures the dynamics of market forces reasonably well. For example, we ignore the feedback between lower electricity prices and higher electricity consumption (the price-elasticity effect). We are unsure whether increased consumption would benefit the local utility or its competitors. More generally, changes over time in electricity consumption and demand, in fuel prices, and in other factors will affect the amount of SC a utility faces. For example, the EIA (1994b) projects a roughly $3 \% / y e a r$ increase in the real price of natural gas to electric utilities between 1992 and 2000.

That the net SC calculated here is the appropriate measure of the potential losses to utility shareholders (or core customers) from retail wheeling. Net SC differs from gross SC, which ignores assets and contracts that have market values greater than book values.

That losses in wholesale-power transactions and any associated stranded commitments can be ignored. The FERC (1994) estimates that 85 to $90 \%$ of SC are associated with retail service.

That each utility's average industrial price accurately reflects the situation facing industrial customers. Although this price includes special rates for some customers (e.g., interruptible rates that are not interrupted and economic-development rates intended to provide discounts) and higher rates for others, it is a reasonable average. Our analysis, however, does not require that each utility's average industrial price accurately reflect the utility's cost to serve industrial customers. For example, if industrial prices are higher than costs because industrial customers subsidize residential customers, the associated loss of revenue will not be recovered from other customers and will constitute a stranded publicpolicy program. 
That the appropriate market for the retail customers of an individual utility includes other suppliers within that NERC region. We ignore opportunities to trade across the NERCregion boundaries; thus, we assume that transmission costs and losses to obtain supplies from outside that region would raise the price enough to make such transactions uneconomical.

- That the effects of future liabilities not presently in rates are small and are offset by other factors not included in our analysis. In some cases, these liabilities (especially those associated with long-term purchased-power contracts) are large.

- That the appropriate competitive electricity price is the average across a NERC region, and that ignoring time-of-use variations in production costs, transmission constraints, and retail prices introduces no major errors into this analysis.

That the annual revenue loss associated with selling electricity to customers at the lower regional price translates dollar for dollar into lower pre-tax earnings. In other words, there are no offsetting operating-cost reductions.

That an appropriate measure of SC is the net present value of the annual earnings loss, which is assumed to continue unchanged for a set number of years. More generally, we assume that the revenue flows of a utility's income statement can be translated directly into the capital stocks of its balance sheet.

That the appropriate discount rate to use in the NPV calculation is the utility's real return on equity.

As part of our continuing work on this project, we will examine closely the effects that these assumptions could have on estimates of stranded commitments. Below are our current thoughts on the possible effects of those assumptions for which we can now hazard a guess. Considering the dynamics of utility, customer, and wholesale-market behaviors will likely lower estimates of SC. Calculating net (vs gross) estimates and adjusting for income taxes leads-correctly-to lower estimates of SC than would (incorrect) calculations that ignore these two factors. Neglecting possible wholesale losses and future liabilities (e.g., deferred income taxes) would underestimate SC. Ignoring the possibility of sales across the boundaries of NERC regions would underestimate $\mathrm{SC}$; on the other hand, the costs and losses associated with longdistance transactions may exceed the $0.44 \notin / \mathrm{kWh}$ factor we assumed. 


\section{CONCLUSIONS}

We developed a rudimentary top-down method to estimate the amount of stranded commitment that each large U.S. investor-owned utility might face as of 1993 . Our best estimates of SC range from $38 \%$ of utility equity ( $\$ 69$ billion) to $54 \%$ of equity ( $\$ 99$ billion). However, even this broad range is subject to considerable uncertainty. Roughly speaking, every $1 \notin / \mathrm{kWh}$ change in the market price of electricity causes up to a $\$ 59$ billion change in the amount of SC nationwide. The states with the biggest potential dollar losses include California, New York, Ohio, and Pennsylvania. The states with the biggest potential percentage losses include Maine, Massachusetts, New Hampshire, and Rhode Island.

Our analyses point to four major conclusions:

- Reported estimates of SC depend strongly on the assumptions made in deriving those numbers. Treat skeptically those estimates that are not well documented.

The most important assumptions are the fraction of a utility's retail load that can obtain electricity supplies in a competitive market and the price of electricity in that competitive market. In addition, the number of years during which the utility suffers this revenue loss is an important determinant of results. Of course, these three sets of assumptions are related to each other.

- The appropriate measure of SC is the net, not the gross, estimate. The net estimate adjusts for utility assets that have a market value above book value.

- Estimates of SC should reflect the effects of federal and state income taxes, which serve to reduce the losses that utility shareholders and customers will ultimately have to absorb.

The amounts of stranded commitment computed here are large both in absolute terms and relative to utility shareholder equity. Developing reasonable and equitable ways to quantify, mitigate, and allocate these costs will likely be a critical precondition to restructuring the U.S. electricity industry. 


\section{ACKNOWLEDGMENTS}

We thank Ben Arikawa, Greg Basheda, Charles Clark, Bruce Edelston, Peter Fox-Penner, Paul Fremont, Paul Galen, Seymour Goldstone, Karen Griffin, Larry Hill, William Hogan, Robijn Hornstra, John Leama, David Meyer, Kevin Porter, Gary Stern, and John Wile for their very helpful comments on a draft of this paper. We thank Stan Hadley and Brendan Kirby for their help in organizing the EIA and FERC data we used in these analyses. We thank Fred O'Hara for editing the report and Ethel Schorn for managing the report's printing and distribution. 


\section{REFERENCES}

S. C. Anderson, J. G. Graham, and W. W. Hogan 1993, Electricity Transition Costs, draft, Harvard Electricity Policy Group, Harvard University, Cambridge, MA, October.

California Public Utilities Commission 1994, Order Instituting Rulemaking on the Commission's Proposed Policies Governing Restructuring California's Electric Services Industry and Reforming Regulation, R.94-04-31, San Francisco, CA, April 20.

S. M. Cohen, D. Kelley, D. F. Ford, and M. Galvin 1994, Electric Utilities, Merrill Lynch Utility Research Group, New York, NY, September 20.

Edison Electric Institute 1993, Statistical Yearbook of the Electric Utility Industry 1992, Washington, DC, October.

Edison Electric Institute 1994, Advance Release of Data for the 1993 Statistical Yearbook of the Electric Utility Industry, Washington, DC, May.

Electric Power Research Institute 1993 TAG Technical Assessment Guide Electricity Supply-1993, EPRI RT-102276-V1R7, Palo Alto, CA, June.

Energy Information Administration 1993, Financial Statistics of Major U.S. Investor-Owned Electric Utilities 1992, DOE/EIA-0437(92)/1, U.S. Department of Energy, Washington, DC, December.

Energy Information Administration 1994a, Annual Electric Utility Report for the Reporting Period 1993, EIA-861, U.S. Department of Energy, Washington, DC.

Energy Information Administration 1994b, Supplement to the Annual Energy Outlook 1994, DOE/EIA-0554(94), U.S. Department of Energy, Washington, DC, March.

Federal Energy Regulatory Commission 1994, Recovery of Stranded Costs by Public Utilities and Transmitting Utilities, Notice of Proposed Rulemaking, Docket No. RM94-7-000, Washington, DC, June 29.

T. Feiler 1994, "Power-Purchase Coǹtracts Could Strand Billions," Public Utilities Fortnightly, 14-15, November 15. 
C. Goldman and T. Belden 1994, "CPUC Investigation on Stranded Costs," Lawrence Berkeley Laboratory, Berkeley, CA, December.

S. Hempling, K. Rose, and R. E. Burns 1994, The Regulatory Treatment of Embedded Costs Exceeding Market Prices: Transition to a Competitive Electric Generation Market, The National Regulatory Research Institute, Columbus, $\mathrm{OH}$, November.

L. Hobart 1994, Statement Before the House of Representatives Subcommittee on Energy and Power, Hearing on Electricity Issues That Have Followed the Enactment of the Energy Policy Act of 1992, on behalf of the American Public Power Association, Washington, DC, July 13.

W. W. Hogan 1994, Stranded Assets and Options for the Transition: Legal Transitions, Compensation, and the Cost of Shifting Costs, Harvard University, Cambridge, MA, January.

R. McCullough and R. Brown 1994, "Electric Industry Restructuring: The Effect on Rates Nationwide," Public Utilities Fortnightly, 20-25, July 15.

Merrill Lynch 1994, United States Utility Industry, Elephant Redux, New York, NY, August 29.

Michigan Public Service Commission 1994, "Opinion and Interim Order Remanding to the Administrative Law Judge for Further Proceedings," Cases No. U-10143 and U-10176, Lansing, MI, April 11.

Moody's Investors Service 1994, US Electric Utilities: Break-Even Analysis Reveals Large Variation in Generating Costs, New York, NY, June.

D. Moskovitz and D. Foy 1994, "Looking for Peace in the Middle of a Nervous Breakdown," The Electricity Journal 7(9), 22-33, November.

J. J. Musial 1994, "Qualifications and Direct Testimony," Cases No. U-10143 and U-10176 before the Michigan Public Service Commission, Detroit Edison, Detroit, MI, August 24.

Niagara Mohawk Power Corp. 1994, The Impacts of Emerging Competition in the Electric Utility Industry, Syracuse, NY, April.

North American Electric Reliability Council 1994, ES\&D, Electricity Supply \& Demand, Version 1.Ia, Princeton, NJ.

Pacific Gas and Electric Company 1994, Competition Transition Charge Testimony, Before the California Public Utilities Commission, Dockets 94-04-031 and 94-04-032, San Francisco, CA, November 18. 
L. J. Perl 1994, Rewriting the Rules of the Road: Retail Wheeling and Competition in Electric Generation, National Economic Research Associates, New York, NY, April.

R. J. Rudden Associates 1994, "Quantifying Competitive Forces in the Electric Industry," The Rudden Resource, Hauppage, NY, June.

San Diego Gas \& Electric Company 1994, Comments of San Diego Gas \& Electric Company on Proposed Policies Governing Restructuring Electric Services Industry and Reforming Regulation, submitted to the California Public Utilities Commission in Docket No. R.94-04-031, San Diego, CA, June 8.

W. D. Steinmeier and L. G. Stuntz 1994, Stranded Costs: A Study on the Treatment of, and Jurisdiction over, Electric Utility Costs During Transition to a More Competitive Industry, prepared for the Edison Electric Institute, Washington, DC, November. 


\section{APPENDIX: DETAILED TABLES}

Table A-1. Four sets of estimates of wholesale electricity prices by NERC region

Alternative estimates of wholesale-market electricity prices $(\alpha / \mathrm{kWh})$

\begin{tabular}{lcccc} 
NERC region & $\begin{array}{c}\text { Average } \\
\text { industrial price }\end{array}$ & $\begin{array}{c}\text { Combined-cycle } \\
\text { price }^{\mathrm{a}}\end{array}$ & $\begin{array}{c}\text { Capacity- } \\
\text { adjusted price }^{\mathrm{a}}\end{array}$ & $\begin{array}{c}\text { Short-term } \\
\text { price }^{\mathrm{a}}\end{array}$ \\
\hline ECAR & 4.26 & 3.65 & 2.93 & 2.44 \\
ERCOT & 4.39 & 4.03 & 2.44 & 2.44 \\
MAAC & 6.59 & 4.55 & 2.44 & 2.44 \\
MAIN & 4.49 & 4.13 & 3.59 & 2.44 \\
MAPP & 4.24 & 3.95 & 2.74 & 2.44 \\
NPCC & 7.41 & 4.46 & 2.44 & 2.44 \\
SERC & 4.67 & 4.01 & 3.63 & 2.44 \\
SPP & 4.48 & 4.09 & 2.80 & 2.44 \\
WSCC & 5.35 & 4.37 & 2.44 & 2.44 \\
U.S. average & 4.92 & 4.17 & 2.47 & 2.44 \\
\hline
\end{tabular}

${ }^{\mathrm{a}}$ These prices include a $0.44 \AA / \mathrm{kWh}$ adder for transmission. The average industrial price implicitly includes transmission costs. 
Table A-2. Estimates of capital and operating costs for a gas-fired combined-cycle combustion turbine

\begin{tabular}{|c|c|}
\hline \multicolumn{2}{|c|}{ Capital Costs } \\
\hline Total cost, $\$ / \mathrm{kW}$ & 595 \\
\hline Unit life, years & 30 \\
\hline Discount rate, $\%$ & 10 \\
\hline \multicolumn{2}{|c|}{ Operating Costs } \\
\hline Fixed O\&M, \$/kW-yr & 26.5 \\
\hline Variable O\&M, c/kWh & 0.4 \\
\hline Heat rate, Btu/kWh & 7,520 \\
\hline Fuel cost, \$/MBtu & 2.61 \\
\hline Fuel cost, $\mathrm{c} / \mathrm{kWh}$ & 1.96 \\
\hline Capacity factor, $\%^{a}$ & 75 \\
\hline \multicolumn{2}{|c|}{ Total Costs, $₫ / \mathrm{kWh}$} \\
\hline Operating & 2.77 \\
\hline Capital & 0.96 \\
\hline Total & 3.73 \\
\hline
\end{tabular}

${ }^{a}$ For the all-retail case, we set the capacity factor at $60 \%$.

Source: Electric Power Research Institute (1993).

Table A-3. Details of stranded-commitments calculation for the case in which only industrial sales are at risk, the market price is the capacity-adjusted price, and losses occur for ten years

\begin{tabular}{lcccccc}
\hline $\begin{array}{l}\text { NERC } \\
\text { region }\end{array}$ & $\begin{array}{c}\text { Sales loss } \\
\text { (TWh/ } \\
\text { year) }\end{array}$ & $\begin{array}{c}\text { Revenue } \\
\text { loss } \\
\text { (billion } \\
\text { \$/year) }\end{array}$ & $\begin{array}{c}\text { Earnings } \\
\text { loss } \\
\text { (billion } \\
\text { \$/year) }\end{array}$ & $\begin{array}{c}\text { NPV of } \\
\text { earnings } \\
\text { loss } \\
\text { (billion \$) }\end{array}$ & $\begin{array}{c}\text { Equity } \\
\text { (billion } \\
\$ \text { ) }\end{array}$ & $\begin{array}{c}\text { Percent } \\
\text { of equity } \\
\text { lost }\end{array}$ \\
\hline ECAR & 151.9 & 2.4 & 1.6 & 10.6 & 26.7 & 39.7 \\
ERCOT & 61.8 & 1.1 & 0.7 & 5.0 & 14.0 & 35.6 \\
MAAC & 69.2 & 2.9 & 1.9 & 12.5 & 23.2 & 53.7 \\
MAIN & 60.8 & 0.9 & 0.6 & 3.7 & 14.1 & 26.3 \\
MAPP & 37.4 & 0.6 & 0.4 & 2.4 & 5.5 & 43.5 \\
NPCC & 47.2 & 2.6 & 1.7 & 11.4 & 24.1 & 47.4 \\
SERC & 111.4 & 1.1 & 0.7 & 4.8 & 29.8 & 16.0 \\
SPP & 75.8 & 1.3 & 0.8 & 5.5 & 13.7 & 40.1 \\
WSCC & 95.0 & 3.0 & 1.9 & 12.9 & 31.0 & 41.6 \\
Totals & 710.5 & 15.8 & 10.2 & 68.8 & 182.1 & 37.7 \\
\hline
\end{tabular}


Table A-4. Details of stranded-commitments calculation for the case in which only industrial sales are at risk, the market price is the capacity-adjusted price, and losses occur for 15 years

\begin{tabular}{lccccc}
\hline $\begin{array}{l}\text { NERC } \\
\text { region }\end{array}$ & $\begin{array}{c}\text { Sales loss } \\
\text { (TWh/ } \\
\text { year) }\end{array}$ & $\begin{array}{c}\text { Revenue loss } \\
\text { (billion } \\
\text { \$/year) }\end{array}$ & $\begin{array}{c}\text { Earnings } \\
\text { loss (billion } \\
\text { \$/year) }\end{array}$ & $\begin{array}{c}\text { NPV of } \\
\text { earnings loss } \\
\text { (billion } \$\end{array}$ & $\begin{array}{c}\text { Percent of } \\
\text { equity lost }\end{array}$ \\
\hline ECAR & 151.9 & 2.4 & 1.6 & 13.6 & 50.7 \\
ERCOT & 61.8 & 1.1 & 0.7 & 6.3 & 45.4 \\
MAAC & 69.2 & 2.9 & 1.9 & 15.9 & 68.5 \\
MAIN & 60.8 & 0.9 & 0.6 & 4.7 & 33.6 \\
MAPP & 37.4 & 0.6 & 0.4 & 3.1 & 55.5 \\
NPCC & 47.2 & 2.6 & 1.7 & 14.6 & 60.5 \\
SERC & 11.4 & 1.1 & 0.7 & 6.1 & 20.4 \\
SPP & 75.8 & 1.3 & 0.8 & 7.0 & 51.2 \\
WSCC & 95.0 & 3.0 & 1.9 & 16.4 & 53.1 \\
Totals & 710.5 & 15.8 & 10.2 & 87.7 & 48.2 \\
\hline
\end{tabular}

Table A-5. Details of stranded-commitments calculation for the case in which only industrial sales are at risk, the market price is the capacity-adjusted price, and losses occur for 5 years

\begin{tabular}{lccccc}
\hline $\begin{array}{l}\text { NERC } \\
\text { region }\end{array}$ & $\begin{array}{c}\text { Sales loss } \\
\text { (TWh/ } \\
\text { year) }\end{array}$ & $\begin{array}{c}\text { Revenue loss } \\
\text { (billion } \\
\text { \$/year) }\end{array}$ & $\begin{array}{c}\text { Earnings } \\
\text { loss (billion } \\
\text { \$/year) }\end{array}$ & $\begin{array}{c}\text { NPV of } \\
\text { earnings loss } \\
\text { (billion \$) }\end{array}$ & $\begin{array}{c}\text { Percent of } \\
\text { equity lost }\end{array}$ \\
\hline ECAR & 151.9 & 2.4 & 1.6 & 6.3 & 23.6 \\
ERCOT & 61.8 & 1.1 & 0.7 & 3.0 & 21.2 \\
MAAC & 69.2 & 2.9 & 1.9 & 7.4 & 32.0 \\
MAIN & 60.8 & 0.9 & 0.6 & 2.2 & 15.7 \\
MAPP & 37.4 & 0.6 & 0.4 & 1.4 & 25.9 \\
NPCC & 47.2 & 2.6 & 1.7 & 6.8 & 28.2 \\
SERC & 111.4 & 1.1 & 0.7 & 2.8 & 9.5 \\
SPP & 75.8 & 1.3 & 0.8 & 3.3 & 23.9 \\
WSCC & 95.0 & 3.0 & 1.9 & 7.7 & 24.8 \\
Totals & 710.5 & 15.8 & 10.2 & 40.9 & 22.5 \\
\hline
\end{tabular}


Table A-6. Details of stranded-commitments calculation for the case in which only industrial sales are at risk, the market price is the capacity-adjusted price plus $1 \mathrm{c} / \mathbf{k W h}$, and losses occur for ten years

\begin{tabular}{lccccc}
\hline $\begin{array}{l}\text { NERC } \\
\text { region }\end{array}$ & $\begin{array}{c}\text { Sales loss } \\
\text { (TWh/ } \\
\text { year) }\end{array}$ & $\begin{array}{c}\text { Revenue loss } \\
\text { (billion } \\
\text { \$/year) }\end{array}$ & $\begin{array}{c}\text { Earnings } \\
\text { loss (billion } \\
\text { \$/year) }\end{array}$ & $\begin{array}{c}\text { NPV of } \\
\text { earnings loss } \\
\text { (billion \$) }\end{array}$ & $\begin{array}{c}\text { Percent of } \\
\text { equity lost }\end{array}$ \\
\hline ECAR & 151.9 & 1.2 & 0.8 & 5.3 & 19.7 \\
ERCOT & 61.8 & 0.5 & 0.3 & 2.3 & 16.3 \\
MAAC & 69.2 & 2.2 & 1.4 & 9.5 & 40.7 \\
MAIN & 60.8 & 0.4 & 0.3 & 1.7 & 12.3 \\
MAPP & 37.4 & 0.2 & 0.1 & 0.8 & 14 \\
NPCC & 47.2 & 2.1 & 1.4 & 9.4 & 38.8 \\
SERC & 111.4 & 0.2 & 0.1 & 0.7 & 2.5 \\
SPP & 75.8 & 0.5 & 0.3 & 2.3 & 16.9 \\
WSCC & 95.0 & 2.0 & 1.3 & 8.9 & 28.8 \\
Totals & 710.5 & 9.4 & 6.1 & 40.8 & 22.4 \\
\hline
\end{tabular}

Table A-7. Details of stranded-commitments calculation for the case in which only industrial sales are at risk, the market price is the capacity-adjusted price minus $1 \mathrm{k} / \mathrm{kWh}$, and losses occur for ten years

\begin{tabular}{lccccc}
\hline $\begin{array}{l}\text { NERC } \\
\text { region }\end{array}$ & $\begin{array}{c}\text { Sales loss } \\
\text { (TWh/ } \\
\text { year) }\end{array}$ & $\begin{array}{c}\text { Revenue loss } \\
\text { (billion } \\
\text { \$/year) }\end{array}$ & $\begin{array}{c}\text { Earnings } \\
\text { loss (billion } \\
\text { \$/year) }\end{array}$ & $\begin{array}{c}\text { NPV of } \\
\text { earnings loss } \\
\text { (billion \$) }\end{array}$ & $\begin{array}{c}\text { Percent of } \\
\text { equity lost }\end{array}$ \\
\hline ECAR & 151.9 & 4.0 & 2.6 & 17.2 & 64.5 \\
ERCOT & 61.8 & 1.8 & 1.1 & 7.7 & 54.9 \\
MAAC & 69.2 & 3.6 & 2.3 & 15.5 & 66.7 \\
MAIN & 60.8 & 1.5 & 0.9 & 6.4 & 45.1 \\
MAPP & 37.4 & 0.9 & 0.6 & 4.0 & 73.1 \\
NPCC & 47.2 & 3.1 & 2.0 & 13.5 & 55.9 \\
SERC & 11.4 & 2.2 & 1.4 & 9.6 & 32.3 \\
SPP & 75.8 & 2.0 & 1.3 & 8.8 & 64.3 \\
WSCC & 95.0 & 3.9 & 2.5 & 17.0 & 55.0 \\
Totals & 710.5 & 22.9 & 14.9 & 99.7 & 54.8 \\
\hline
\end{tabular}


Table A-8. Details of stranded-commitments calculation for the case in which all retail sales are at risk, the market price is the combined-cycle unit cost, and losses occur for ten years

\begin{tabular}{lccccr}
\hline $\begin{array}{l}\text { NERC } \\
\text { region }\end{array}$ & $\begin{array}{c}\text { Sales loss } \\
\text { (TWh/ } \\
\text { year) }\end{array}$ & $\begin{array}{c}\text { Revenue loss } \\
\text { (billion } \\
\text { \$/year) }\end{array}$ & $\begin{array}{c}\text { Earnings } \\
\text { loss (billion } \\
\text { \$/year) }\end{array}$ & $\begin{array}{c}\text { NPV of } \\
\text { earnings loss } \\
\text { (billion \$) }\end{array}$ & $\begin{array}{r}\text { Percent of } \\
\text { equity lost }\end{array}$ \\
\hline ECAR & 250.9 & 3.1 & 2.0 & 13.3 & 49.8 \\
ERCOT & 7.2 & 0.0 & 0.0 & 0.1 & 0.6 \\
MAAC & 201.1 & 3.6 & 2.3 & 15.5 & 66.8 \\
MAIN & 115.6 & 1.3 & 0.9 & 5.9 & 41.7 \\
MAPP & 37.9 & 0.1 & 0.1 & 0.4 & 7.3 \\
NPCC & 209.0 & 8.2 & 5.4 & 36.0 & 149.3 \\
SERC & 244.7 & 1.4 & 0.9 & 6.1 & 20.6 \\
SPP & 97.1 & 0.6 & 0.4 & 2.6 & 19.2 \\
WSCC & 205.8 & 4.4 & 2.9 & 19.2 & 62.1 \\
Totals & 1369.4 & 22.7 & 14.8 & 99.2 & 54.5 \\
\hline
\end{tabular}

Table A-9. Details of stranded-commitments calculation for the case in which all retail sales are at risk, the market price is the combined-cycle unit cost, and losses occur for 15 years

\begin{tabular}{lccccr}
\hline $\begin{array}{l}\text { NERC } \\
\text { region }\end{array}$ & $\begin{array}{c}\text { Sales loss } \\
\text { (TWh/ } \\
\text { year) }\end{array}$ & $\begin{array}{c}\text { Revenue loss } \\
\text { (billion } \\
\text { \$/year) }\end{array}$ & $\begin{array}{c}\text { Earnings } \\
\text { loss (billion } \\
\text { \$/year) }\end{array}$ & $\begin{array}{c}\text { NPV of } \\
\text { earnings loss } \\
\text { (billion \$) }\end{array}$ & $\begin{array}{r}\text { Percent of } \\
\text { equity lost }\end{array}$ \\
\hline ECAR & 250.9 & 3.1 & 2.0 & 17.0 & 63.5 \\
ERCOT & 7.2 & 0.0 & 0.0 & 0.1 & 0.8 \\
MAAC & 201.1 & 3.6 & 2.3 & 19.8 & 85.2 \\
MAIN & 115.6 & 1.3 & 0.9 & 7.5 & 53.1 \\
MAPP & 37.9 & 0.1 & 0.1 & 0.5 & 9.4 \\
NPCC & 209.0 & 8.2 & 5.4 & 45.9 & 190.4 \\
SERC & 244.7 & 1.4 & 0.9 & 7.8 & 26.3 \\
SPP & 97.1 & 0.6 & 0.4 & 3.3 & 24.5 \\
WSCC & 205.8 & 4.4 & 2.9 & 24.5 & 79.2 \\
Totals & 1369.4 & 22.7 & 14.8 & 126.5 & 69.5 \\
\hline
\end{tabular}


Table A-10. Details of stranded-commitments calculation for the case in which all retail sales are at risk, the market price is the combined-cycle unit cost, and losses occur for 5 years

\begin{tabular}{lrcccr}
\hline $\begin{array}{l}\text { NERC } \\
\text { region }\end{array}$ & $\begin{array}{c}\text { Sales loss } \\
\text { (TWh/ } \\
\text { year) }\end{array}$ & $\begin{array}{c}\text { Revenue loss } \\
\text { (billion } \\
\text { \$/year) }\end{array}$ & $\begin{array}{c}\text { Earnings } \\
\text { loss (billion } \\
\text { \$/year) }\end{array}$ & $\begin{array}{c}\text { NPV of } \\
\text { earnings loss } \\
\text { (billion \$) }\end{array}$ & $\begin{array}{c}\text { Percent of } \\
\text { equity lost }\end{array}$ \\
\hline ECAR & 250.9 & 3.1 & 2.0 & 7.9 & 29.6 \\
ERCOT & 7.2 & 0.0 & 0.0 & 0.1 & 0.4 \\
MAAC & 201.1 & 3.6 & 2.3 & 9.2 & 39.8 \\
MAIN & 115.6 & 1.3 & 0.9 & 3.5 & 24.8 \\
MAPP & 37.9 & 0.1 & 0.1 & 0.2 & 4.4 \\
NPCC & 209.0 & 8.2 & 5.4 & 21.4 & 88.8 \\
SERC & 244.7 & 1.4 & 0.9 & 3.7 & 12.3 \\
SPP & 97.1 & 0.6 & 0.4 & 1.6 & 11.4 \\
WSCC & 205.8 & 4.4 & 2.9 & 11.4 & 37.0 \\
Totals & 1369.4 & 22.7 & 14.8 & 59.0 & 32.4 \\
\hline
\end{tabular}

Table A-11. Details of stranded-commitments calculation for the case in which all retail sales are at risk, the market price is the combined-cycle unit cost plus $1 \mathrm{c} / \mathrm{kWh}$, and losses occur for ten years

\begin{tabular}{lccccr}
\hline $\begin{array}{l}\text { NERC } \\
\text { region }\end{array}$ & $\begin{array}{c}\text { Sales loss } \\
\text { (TWh/ } \\
\text { year) }\end{array}$ & $\begin{array}{c}\text { Revenue loss } \\
\text { (billion } \\
\text { \$/year) }\end{array}$ & $\begin{array}{c}\text { Earnings } \\
\text { loss (billion } \\
\text { \$/year) }\end{array}$ & $\begin{array}{c}\text { NPV of } \\
\text { earnings loss } \\
\text { (billion \$) }\end{array}$ & $\begin{array}{r}\text { Percent of } \\
\text { equity lost }\end{array}$ \\
\hline ECAR & 250.9 & 1.2 & 0.8 & 5.1 & 19.1 \\
ERCOT & 7.2 & 0.0 & 0.0 & 0.0 & 0.1 \\
MAAC & 201.1 & 1.8 & 1.2 & 8.0 & 34.3 \\
MAIN & 115.6 & 0.5 & 0.4 & 2.4 & 16.9 \\
MAPP & 37.9 & 0.0 & 0.0 & 0.0 & 0.0 \\
NPCC & 209.0 & 6.3 & 4.1 & 27.6 & 114.4 \\
SERC & 244.7 & 0.0 & 0.0 & 0.1 & 0.4 \\
SPP & 97.1 & 0.2 & 0.1 & 0.8 & 5.5 \\
WSCC & 205.8 & 2.4 & 1.6 & 10.5 & 33.8 \\
Totals & 1369.4 & 12.5 & 8.1 & 54.4 & 29.9 \\
\hline
\end{tabular}


Table A-12. Details of stranded-commitments calculation for the case in which all retail sales are at risk, the market price is the combined-cycle unit cost minus $1 \mathrm{c} / \mathbf{k W h}$, and losses occur for ten years

\begin{tabular}{lccccr}
\hline $\begin{array}{l}\text { NERC } \\
\text { region }\end{array}$ & $\begin{array}{c}\text { Sales loss } \\
\text { (TWh/ } \\
\text { year) }\end{array}$ & $\begin{array}{c}\text { Revenue loss } \\
\text { (billion } \\
\text { \$/year) }\end{array}$ & $\begin{array}{c}\text { Earnings } \\
\text { loss (billion } \\
\text { \$/year) }\end{array}$ & $\begin{array}{c}\text { NPV of } \\
\text { earnings loss } \\
\text { (billion \$) }\end{array}$ & $\begin{array}{c}\text { Percent of } \\
\text { equity lost }\end{array}$ \\
\hline ECAR & 250.9 & 5.6 & 3.6 & 24.3 & 90.7 \\
ERCOT & 7.2 & 0.1 & 0.1 & 0.4 & 2.9 \\
MAAC & 201.1 & 5.6 & 3.6 & 24.3 & 104.6 \\
MAIN & 115.6 & 2.5 & 1.6 & 10.9 & 77.4 \\
MAPP & 37.9 & 0.5 & 0.3 & 2.1 & 37.3 \\
NPCC & 209.0 & 10.3 & 6.7 & 45.1 & 187.1 \\
SERC & 244.7 & 3.9 & 2.5 & 16.8 & 56.4 \\
SPP & 97.1 & 1.6 & 1.0 & 6.9 & 50.2 \\
WSCC & 205.8 & 6.5 & 4.2 & 28.2 & 91.1 \\
Totals & 1369.4 & 36.4 & 23.7 & 158.9 & 87.3 \\
\hline
\end{tabular}

Table A-13. Projected capacity margins by NERC region

\begin{tabular}{lcc}
\hline \multirow{2}{*}{ NERC region } & \multicolumn{2}{c}{ Capacity margins (\%) } \\
\cline { 2 - 3 } ECAR & 1994 & 2003 \\
ERCOT & 18.0 & 17.6 \\
MAAC & 21.5 & 20.3 \\
MAIN & 20.1 & 20.2 \\
MAPP & 16.6 & 17.1 \\
NPCC & 19.0 & 18.7 \\
SERC & 25.3 & 24.6 \\
SPP & 16.2 & 16.4 \\
WSCC & 18.9 & 18.1 \\
Totals & 24.5 & 24.0 \\
\hline
\end{tabular}

Source: North American Electric Reliability Council (1994) 


\section{INTERNAL DISTRIBUTION}

1. D. Bauer

2. L. Baxter

3. V. D. Baxter

4. L. Berry

5. D. S. Bjornstad

6. R. Braid

7. M. A. Brown

8. J. B. Cannon

9. F. C. Chen

10. J. Christian

11. G. Courville

12. T. R. Curlee

13. P. D. Fairchild

14. S. Hadley

15. L. J. Hill

16. E. Hillsman

17. E. Hirst

18. P. J. Hughes

19. M. A. Kuliasha
20. R. Lee

21. P. Leiby

22. J. M. MacDonald

23. V. C. Mei

24. D. E. Reichle

25. D. T. Rizy

26. A. C. Schaffhauser

27. M. Schweitzer

28. R. B. Shelton

29. J. Tomlinson

30. B. E. Tonn

31. J. Van Dyke

32. J. VanCoevering

33. J. M. Veigel (ORAU)

34. T. J. Wilbanks

35. ORNL Patent Office

36. Central Research Office

37. Document Reference Section

38. Laboratory Records (RC)

39-41. Laboratory Records Dept.

\section{EXTERNAL DISTRIBUTION}

42. Dr. Douglas R. Bohi, Director, Energy and Natural Resources Division, Resources for the Future, 1616 P Street, N.W., Washington, DC 20036

43. Dr. Thomas E. Drabek, Professor, Department of Sociology, University of Denver, Denver, CO 80208-0209.

44. Dr. Stephen G. Hildebrand, Director, Environmental Sciences Division, Oak Ridge National Laboratory, Post Office Box 2008, Oak Ridge, TN 37831-6037

45. Calvin MacCracken, President, Calmac Manufacturing Corporation, 101 West Sheffield Avenue, P. O. Box 710, Englewood, NJ 07631

46. Jacqueline B. Shrago, Director, Office of Technology Transfer, 405 Kirkland Hall, Vanderbilt University, Nashville, TN 37240

47. Mr. George F. Sowers, P. E., Senior Vice President, Law Companies Group, Inc., 114 Townpark Drive, Suite 250, Kennesaw, GA 30144-5599

48. Dr. C. Michael Walton, Emest H. Cockrell Centennial Chair in Engineering and Chairman, Department of Civil Engineering, University of Texas at Austin, Austin, TX 78712-1076

49.-50. OSTI, U. S. Department of Energy, P. O. Box 62, Oak Ridge, TN 37831

51. Office of Assistant Manager for Energy Research and Development, DOE/ORO, P. O. Box 2001, Oak Ridge, TN 37831-8600

52.-800. External Energy and Global Change Analysis Section distribution mailing list and extra copies to E.M. Schorn, $4500 \mathrm{~N}, \mathrm{H}-19 \mathrm{~A}$ 